\title{
The role of tachykinin receptor antagonists in the prevention of bronchial hyperresponsiveness, airway inflammation and cough
}

\author{
C. Advenier*, V. Lagente**, E. Boichot**
}

The role of tachykinin receptor antagonists in the prevention of bronchial hyperresponsiveness, airway inflammation and cough. C. Advenier, V. Lagente, E. Boichot. CERS Journals Ltd 1997.

ABSTRACT: Several recent observations suggest that tachykinins, such as substance $P$ and neurokinin $A$, might be involved in the pathogenesis of bronchopulmonary alterations. Progress in investigations on the physiological and pathological roles of tachykinins has been greatly facilitated by the availability of a number of highly selective nonpeptide antagonists for tachykinin neurokinin 1,2 and $3\left(\mathbf{N K}_{1}\right.$, $\mathrm{NK}_{2}$ and $\mathrm{NK}_{3}$ ) receptors.

The use of selective tachykinin $\mathrm{NK}_{2}$ receptor antagonists suggests that tachykinin $\mathrm{NK}_{2}$ receptor stimulation plays an important role in the development of airway hyperresponsiveness in the guinea-pig. Others studies have also indicated that tachykinin $\mathrm{NK}_{1}$-receptors are involved in immediate or delayed neurogenic inflammation including microvascular leakage and the subsequent increase in plasma protein extravasation. A role for the sensory neuropeptide system has also been proposed in cough, as shown by the observation that the antitussive effect of tachykinin $\mathrm{NK}_{2}$ receptor antagonists has clearly been demonstrated in several experimental conditions, but the effect of tachykinin $\mathrm{NK}_{1}$ receptor antagonists is still debated.

Taken together, the results obtained with the various selective receptor antagonists provide pharmacological evidence that tachykinins play a role in delayed bronchopulmonary alterations and suggest that tachykinin receptor antagonists may be useful for investigating mechanisms and possibly reducing airway functional alterations in asthmatic patients.

Eur Respir J 1997; 10: 1892-1906.

\begin{abstract}
*Laboratoire de Pharmacologie Respiratoire, Faculté de Médecine Paris-Ouest, Université Paris V, Paris, France. **Laboratoire de Pharmacodynamie et de Pharmacologie Moléculaire, INSERM U 456, Faculté des Sciences Pharmaceutiques et Biologiques, Université de Rennes 1, Rennes, France.
\end{abstract}

Correspondence: V. Lagente

Laboratoire de Pharmacodynamie et de Pharmacologie Moléculaire

INSERM U 456

Faculté des Sciences Pharmaceutiques et Biologiques

Université Rennes 1

2, Avenue du Professeur Léon Bernard 35343 Rennes cedex

France

Keywords: Airway inflammation cough

hyperresponsiveness

substance P

tachykinin receptor

Received: October 241996

Accepted after revision April 161997
The excitatory nonadrenergic noncholinergic (NANC) system, involving various neuropeptides of the tachykinin family, such as substance P (SP), neurokinin A (NKA), neurokinin $\mathrm{B}(\mathrm{NKB})$ and calcitonin gene-related peptide (CGRP), as transmitters, has now been well characterized. In airways, SP, NKA and CGRP are co-localized in the sensory unmyelinated C-fibres, which innervate all compartments of the airway wall from the trachea down to the bronchioles. C-fibre endings are found within the epithelium. They form a dense plexus in the subepithelial lamina propria, supply the glands, ramify within the smooth muscle layer and make direct contacts with postganglionic parasympathetic neurons, located in the local ganglion. In the trachea, this sensory innervation is almost exclusively derived from sensory vagal neurons, supplied by the jugular ganglion, whilst that of the lung is of mixed origin with a predominating vagal and a smaller spinal contribution [1-5]. The NANC system can be activated by different stimuli, which affect the chemosensitive $\mathrm{C}$-fibre afferents in airways and lead to a local release of tachykinins that are responsible for several biological effects in the bronchopulmonary system: bronchospasm; increase in vascular permeability from postcapillary venules; stimulation of glandular secre- tion; facilitation of cholinergic neurotransmission; and recruitment and activation of some types of inflammatory cells. Sensory nerves also mediate respiratory defence reflexes, such as coughing, sneezing and secretion of mucus (fig. 1).

From these data, it has been hypothesized that abnormal stimulation of the sensory nerve terminals, e.g. induced by epithelial shedding as seen in asthma, results in enhanced release of tachykinins in the airway wall with subsequent exaggeration of inflammation. This concept of "neurogenic inflammation" introduces sensory nerve fibres as important components in the pathogenesis of asthma.

The biological actions of tachykinins are mediated via three types of receptors, denoted neurokinins $1-3\left(\mathrm{NK}_{1}\right.$, $\mathrm{NK}_{2}$ and $\mathrm{NK}_{3}$ ), which have the highest affinity for SP, NKA and NKB, respectively. This receptor classification has been established from receptor-binding and functional studies. It has now been recognized that the expression of tachykinin $\mathrm{NK}_{3}$ receptors is confined mainly to the central and peripheral nervous system, whilst tachykinin $\mathrm{NK}_{1}$ and tachykinin $\mathrm{NK}_{2}$ receptors are expressed both in the central and peripheral nervous system and in target organs, including airways [5-10]. According 


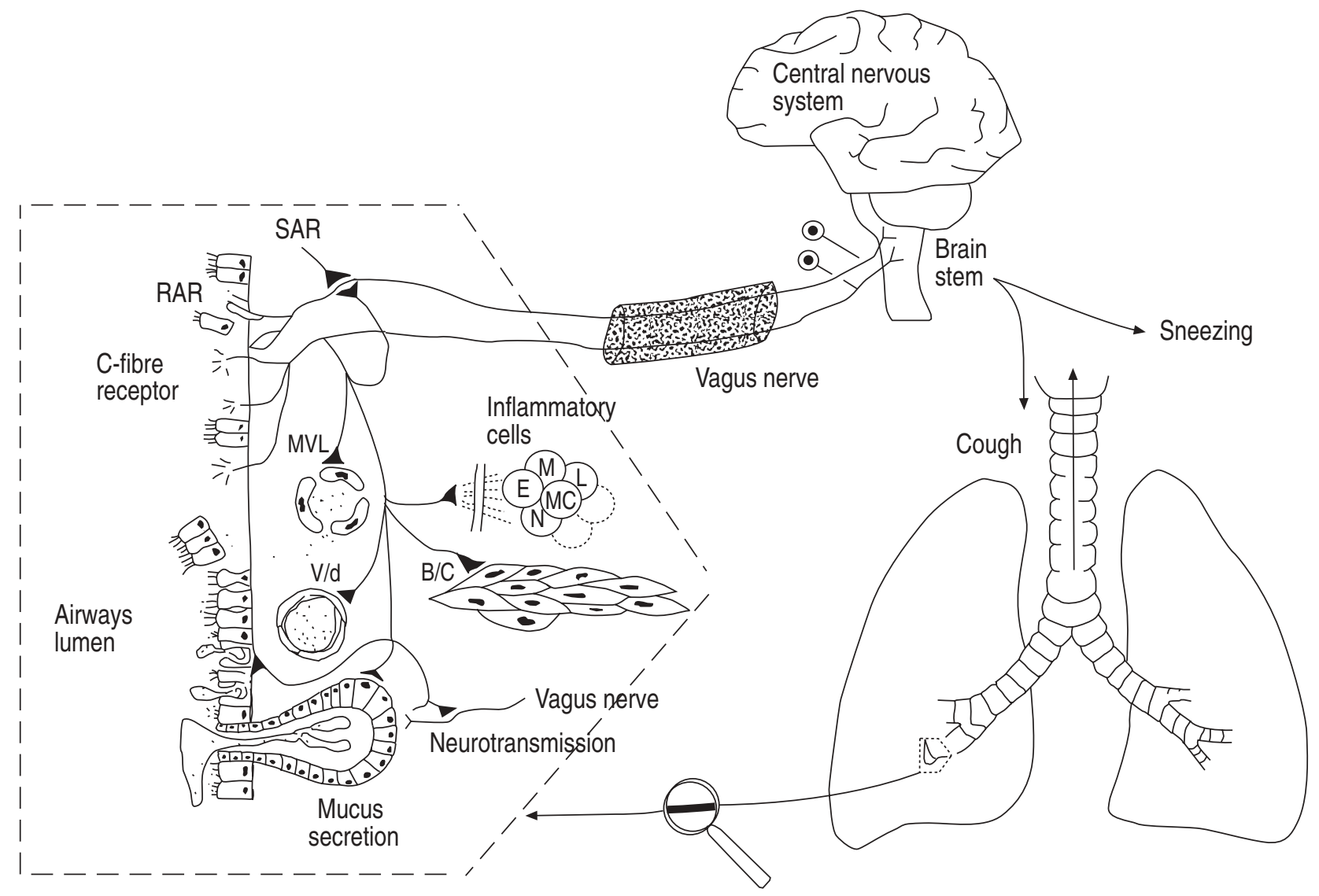

Fig. 1. - Schematic representation of the nonadrenergic noncholinergic (NANC) nerves of airways. SAR: slowly adapting pulmonary stretch receptor; RAR: rapidly adapting pulmonary stretch receptor; MVL: microvascular leakage; V/d:vasodilatation; B/C: bronchoconstriction; E: eosinophils; M: monocytes/macrophages; L: lymphocytes; MC: mast cells; N: neutrophils. (Adapted from [1-5]).

to the present state of our knowledge, SP and NKA seem to play an important role in the respiratory system. Therefore, the presence of tachykinin $\mathrm{NK}_{1}$ and tachykinin $\mathrm{NK}_{2}$ receptors on different target cells ultimately determines the biological consequences of the activation of the NANC system, although an activation of tachykinin $\mathrm{NK}_{3}$ receptors is not completely excluded $[11,12]$.

Progress in investigations on the physiological and pathological roles of tachykinins and on tachykinin receptor classification has been greatly facilitated by the availability of a number of highly selective nonpeptide antagonists for tachykinin $\mathrm{NK}_{1}, \mathrm{NK}_{2}$ and $\mathrm{NK}_{3}$ receptors (table 1 and fig. 2) [28]. These compounds can be regarded as suitable tools for the investigation of the pharmacological effect of tachykinins. Moreover, tachykinin $\mathrm{NK}_{1}$ and $\mathrm{NK}_{2}$ dual receptor antagonists, FK 224, S.16474 and MDL 105,212A, have been described [25-27]. With the development of newer and more selective ligands for the various receptors, it has become possible to clarify the respective contribution of tachykinin $\mathrm{NK}_{1}, \mathrm{NK}_{2}$ and $\mathrm{NK}_{3}$ activation to the pharmacological effects of tachykinins (table 2).

Airway hyperresponsiveness, an enhanced bronchoconstrictor response to many different stimuli, is a key feature of asthma and relates closely to the severity of the disease, the frequency of symptoms, and the need for treatment [31-33]. There is some evidence that hyperresponsiveness is associated with inflammation in the airways. Histopathological studies carried out on asthmatics who died during asthma attacks have demonstrated marked inflammation in the airways, with infiltration of inflammatory cells, particularly eosinophils, alteration of the airway epithelium, and plugging of the airway lumen by viscous secretions [34].

It is increasingly apparent that different cells are involved in the pathogenesis of asthma, and that these cells produce a variety of mediators that interact in a complex way to produce a number of pathological effects,

Table 1. - Tachykinin receptor antagonists

\begin{tabular}{|c|c|c|c|}
\hline Type & Code & First author & [Ref.] \\
\hline \multirow{6}{*}{$\mathrm{NK}_{1}$ selective } & CP 96,345 & SNIDER & [13] \\
\hline & RP 67,580 & GARRET & [14] \\
\hline & FK 888 & FUJJI & [15] \\
\hline & $\begin{array}{l}\text { SR } 140333 \\
\text { (nolpitantium) }\end{array}$ & EMONDS-ALT & [16] \\
\hline & LY 303870 & GITTER & [17] \\
\hline & GR 203040 & BeAtTIE & [18] \\
\hline \multirow[t]{5}{*}{$\mathrm{NK}_{2}$ selective } & MEN 10,376 & MAGGI & [19] \\
\hline & SR 48968 & EMONDS-Alt & [20] \\
\hline & (saredutant) & ADVENIER & [21] \\
\hline & MEN 10,627 & MAGGI & [22] \\
\hline & GR 159897 & BALL & [23] \\
\hline $\mathrm{NK}_{3}$ selective & SR 142801 (osanetant) & EMONDS-ALT & [24] \\
\hline \multirow{3}{*}{ Dual $\mathrm{NK}_{1}+\mathrm{NK}_{2}$} & FK 224 & MURAI & [25] \\
\hline & S.16474 & RoBINGaU & [26] \\
\hline & MDL $105,212 \mathrm{~A}$ & KudLacz & [27] \\
\hline
\end{tabular}

NK: neurokinin. 
a)<smiles>CN1Cc2ccccc2OCN(C)C2C3C=CC(N3)C(c3ccccc3)C2c2ccccc21</smiles>

CP 96,345 ( $\mathrm{NK}_{1}$ selective)

e)<smiles>CC(=O)NC1(c2ccccc2)CCN(CC[C@@H](C)c2ccc(Cl)c(Cl)c2)CC1</smiles>

b)<smiles>COc1ccccc1CC(N)N1CC23CC(c4ccccc4)(c4ccccc4)CCC(=O)C2(C1)C3</smiles>

c)<smiles>COc1ccccc1CNC1CCCNC1c1ccccc1</smiles>

d)<smiles>CC(C)Oc1cccc(CC(=O)N2CCC[C@H](c3ccc(Cl)c(Cl)c3)[C@H]2CC[N+]2([Cl+])C=CC(c3ccccc3)CC2)c1</smiles>

SR 140333 ( $\mathrm{NK}_{1}$ selective)

f)

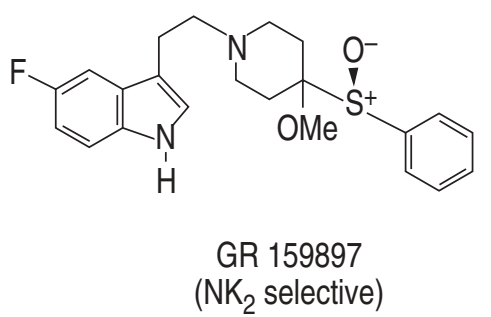

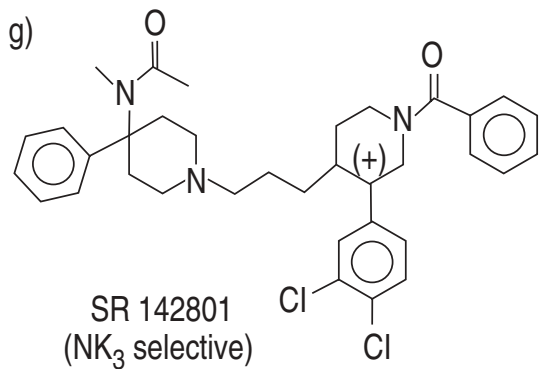

Fig. 2. - Chemical structures of nonpeptide tachykinin receptor antagonists. a) CP 96,345: [2S,3S)-cis-2(diphenylmethyl)-N-[2-methoxyphenyl)methyl]-1-azabicyclo[2.2.2] octane-3-amine; b) RP 67580: (3aR,7aR)-7,7-diphenyl-2-[1-imino-2(2-methoxyphenyl)-ethyl]perhydroisonindol-4-one; c) CP 99,994: (+)-(2S,3S)-3-(2-methoxy-benzylamino)-2-phenylpiperadine; d) SR 140333: (S)-1-[2-[3-(3,4-Dichlorophenyl)-1-(3-isopropoxyphenylacetyl) piperidino-3-yl]ethyl]-4-phenyl-1-azoniabicyclo [2.2.2]octane; e) SR 48968: (S)-N-methyl-N[4-acetylamino-4-phenylpiperidino)-2-(3,4-dichlorophenyl)butyl]-benzamide; f) GR 159897: (R)-1-[2-(5-fluoro-1H-indol-3-yl)ethyl]-4-methoxy-4-[(phenylsulfinyl)methyl]-piperidine; g) SR 142801; (R)-(N)-(1-(3-(1-benzoyl-3-(3,4-dichlorophenyl)piperidino-3-yl)propyl)-4-phenylpiperidino-4-yl)-N-methylacetamide. $\mathrm{NK}_{1}, \mathrm{NK}_{2}, \mathrm{NK}_{3}$ : neurokinins 1,2 and 3 , respectively.

which, together, contribute to bronchial hyperresponsiveness. Among these mediators, tachykinins appear to play a major role, since they contribute to the development of "neurogenic inflammation" [3, 35]. Moreover, several mediators involved in the development or maintenance of the inflammatory response, could also enhance the production or the activity of tachykinins [36-39].
A role for the sensory neuropeptide system has also been proposed in cough. According to the recent review by WIDDICOMBE [40], the cough reflex is usually considered to be mediated by intraepithelial nerves and by two types of sensory receptors, the pulmonary and bronchial C-fibre receptors with nonmyelinated afferents, and the rapidly adapting pulmonary stretch receptors

Table 2. - Receptors involved in the pharmacological effects of tachykinins (substance $P$, neurokinin $A$ and neurokinin B) in the airways

\begin{tabular}{|c|c|c|c|c|}
\hline \multicolumn{2}{|c|}{ Effects } & \multicolumn{3}{|c|}{ Receptor subtypes } \\
\hline & & $\mathrm{NK}_{1}$ & $\mathrm{NK}_{2}$ & $\mathrm{NK}_{3}$ \\
\hline Nerve activation & Increase in ganglionic transmission & + & + & +++ \\
\hline \multirow[t]{6}{*}{ Bronchial smooth muscle } & Contraction of ferret trachea & + & +++ & \\
\hline & Contraction of hamster trachea & & $+++\left(\mathrm{NK}_{2 \mathrm{~B}}\right)$ & \\
\hline & Contraction of guinea-pig trachea & ++ & +++ & \\
\hline & Contraction of guinea-pig bronchus & + & $+++\left(\mathrm{NK}_{2 \mathrm{~A}}\right)$ & \\
\hline & Contraction of human bronchus & + & +++ & \\
\hline & Relaxation of rat trachea* & ++ & & \\
\hline Vascular permeability & Plasma protein extravasation & +++ & +/++ & \\
\hline Recruitment and activation & Chemotaxis (guinea-pig, human) & +++ & & \\
\hline \multirow[t]{4}{*}{ of inflammatory cells } & Lymphocyte proliferation (human) & +++ & + & \\
\hline & Increase in neutrophil motility & +++ & + & \\
\hline & Monocyte/macrophage stimulation & ++ & ++ & \\
\hline & Mast cell activation & $?$ & $?$ & \\
\hline \multirow[t]{4}{*}{ Stimulation of secretion } & Mucus in guinea-pig trachea & +++ & \pm & \\
\hline & Mucus in ferret trachea & +++ & \pm & \\
\hline & Mucus in human bronchus & +++ & \pm & \\
\hline & $\mathrm{Cl}^{-}$from epithelial cells & +++ & \pm & \\
\hline \multirow[t]{3}{*}{ Bronchial hyperresponsiveness } & $\begin{array}{l}\text { Increase of ACh-induced bronchoconstriction } \\
\text { (guinea-pig) }\end{array}$ & & +++ & +++ \\
\hline & (mouse) & ++ & & \\
\hline & $\begin{array}{l}\text { Increase of nistamine-1nduced } \\
\text { microvascular leakage (guinea-pig) }\end{array}$ & +++ & & +++ \\
\hline Cough & & + & +++ & $?$ \\
\hline
\end{tabular}

*: contractile effect has also been reported [29], *: a nonreceptor effect has been suggested [30]. NK: neurokinin; ACh: acetylcholine. Receptor subtypes involvement: +++: very strong; ++: strong; +: moderate; \pm : doubtful; ?: questionable. 
(RARs), sometimes called irritant receptors, with small diameter $(\mathrm{A} \delta)$ myelinated fibres. The evidence that RARs cause cough is clearly established, and is based on their localization at the sites of the airways most sensitive to cough (larynx and carina) [41-43], and on the fact that all the mechanical and chemical stimuli that lead to cough also excite them $[40,44]$. In contrast, the role of pulmonary and bronchial C-fibre endings and tachykinins in cough is not yet clearly established, but some evidence suggests that the stimulation of such receptors elicits an increased sensitivity of the afferent nervous pathways associated with the stimulation of RARs [40].

The aim of the present review is to describe the involvement of tachykinins in airway inflammation, bronchial hyperresponsiveness and cough, and to describe a potential therapeutic use of new antagonists.

\section{Tachykinins, airway inflammation and bronchial hyperresponsiveness}

\section{Airway hyperresponsiveness}

Airway hyperresponsiveness is an important feature of asthma and is characterized by a nonspecific exaggerated response to bronchoconstrictor agents, such as histamine and acetylcholine [31-33]. Experimentally, bronchial hyperresponsiveness is expressed by the leftward shift of the concentration-response curves following aerosol administration of histamine or methacholine. In asthmatic patients, bronchial hyperresponsiveness results in a significant decrease in the provocative concentration of histamine or methacholine causing a $20 \%$ decrease in forced expiratory volume in one second (PC20).

Bronchial hyperresponsiveness is the expression of an exaggerated bronchopulmonary response associated with airway inflammation, involving vascular alterations, increase in bronchial secretions, recruitment and activation of inflammatory cells.

\section{Involvement of tachykinins in airway hyperresponsive- ness}

Several observations suggest that tachykinins, such as SP and NKA, might be involved in the pathogenesis of airway hyperresponsiveness. Indeed, recent studies have reported that exposure of guinea-pigs to a single aerosol of either capsaicin (the pungent extract of red pepper, which releases endogenous sensory neuropeptides) [45] or SP elicited airway hyperresponsiveness to exogenous bronchoconstrictor agents [46-50]. NKA also enhanced methacholine response for up to 4 weeks in monkeys [51]. In asthmatic patients, exposure to SP enhanced maximal airway narrowing to methacholine $24 \mathrm{~h}$ later [52].

Conversely, chronic treatment with high doses (i.p.) of capsaicin, which depletes tachykinins from NANC nerves, eliminated airway hyperresponsiveness induced by acute capsaicin [48], citric acid [53], ovalbumin [54, 55] toluene diisocyanate [56], endotoxin [57], plateletactivating factor (PAF) [58], respiratory viral infection [59], and ozone [60] in guinea-pigs, dinitro-fluorobenzene [61] and toluene diisocyanate [62] in mice, and Altenaria tenuis aerosol in rabbits [63].
Tachykinin receptor antagonists and bronchial hyperresponsiveness

The involvement of tachykinins in the development of airway hyperresponsiveness has also been demonstrated using tachykinin receptor antagonists. Indeed, a single treatment with the tachykinin $\mathrm{NK}_{2}$ receptor antagonist, SR 48968 (Saredutant) [64], or with the dual tachykinin $\mathrm{NK}_{1}$ and $\mathrm{NK}_{2}$ receptor antagonists, MDL 105,212 [65] or FK 224 [66], prevented the antigeninduced airway hyperresponsiveness in the guinea-pig, whereas the tachykinin $\mathrm{NK}_{1}$ receptor antagonists, SR 140333 [64] (fig. 3) or FK 888 [66], did not. Inhaled SP in phosphoramidon-pretreated guinea-pig also induced bronchial hyperresponsiveness [49]. In this model again, SR 48968, but not SR 140333, suppressed the leftward shift of the dose-response curve to acetylcholine observed after exposure of phosphoramidon-pretreated guineapigs to SP [67], and these data also support a role for tachykinin $\mathrm{NK}_{2}$ receptor stimulation in the development of airway hyperresponsiveness. Similar conclusions were reported by YoshIHARA et al. [68], who showed that SR 48968 prevented the potentiation of antigen-induced bronchoconstriction by cold air in guinea-pigs; and by PerRetTi et al. [69], who reported that the specific and long-acting peptidic antagonist, MEN 10,627, inhibited PAF-induced airway hyperresponsiveness in the guineapig. Finally, TOCKER et al. [70] reported that vagal stimulation in the presence of atropine potentiated pulmonary anaphylaxis in sensitized perfused guinea-pig lung; this potentiation was abolished by SR 48968, whereas NKA, but not SP, was able to mimic the effects of vagal stimulation.

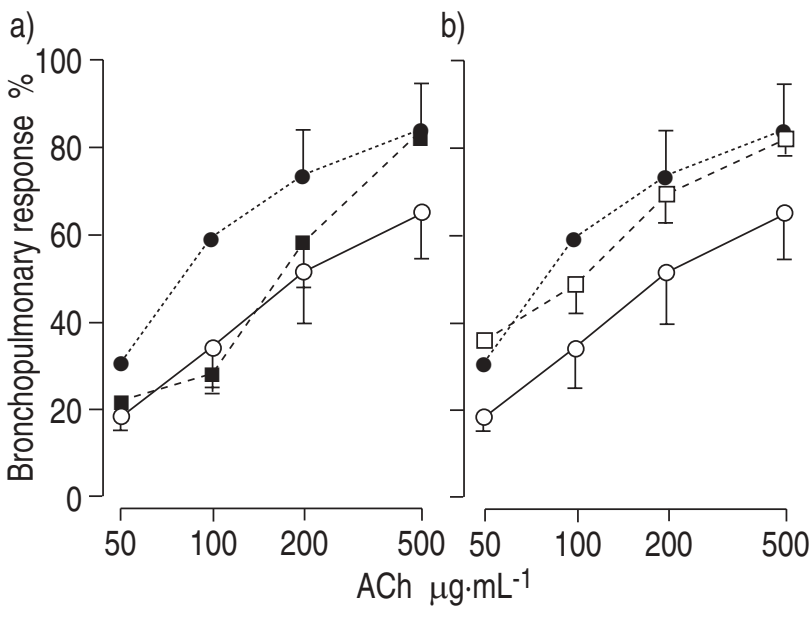

Fig. 3. - Effect of: a) SR 48968; and b) SR 140333 on antigeninduced airway hyperresponsiveness. Hartley guinea-pigs were sensitized by ovalbumin (OA) aerosol. After 15-20 days they were challenged by exposure to successive solutions of 10,100, 1000, 5000 and $10000 \mathrm{OA} \mu \mathrm{g} \cdot \mathrm{mL}^{-1}$ for $15 \mathrm{~min}$ each. The bronchopulmonary response of anaesthetized and ventilated guinea-pigs was assessed 48 $\mathrm{h}$ after exposure to either OA challenge or saline. After $10 \mathrm{~min}$, successive administrations of 50,100, 200 and $500 \mu \mathrm{g} \cdot \mathrm{mL}^{-1}$ acetylcholine (ACh) aerosol were given for $1 \mathrm{~min}$ each at $10 \mathrm{~min}$ intervals. The bronchopulmonary response was expressed as mean \pm SEM percentage of that obtained by clamping the tracheal cannula. Sensitized guineapigs were treated, $30 \mathrm{~min}$ before $\mathrm{OA}$ exposure with $1 \mathrm{mg} \cdot \mathrm{kg}^{-1}$ i.p. of SR 48968 or of SR 140333. - - : saline $(n=5)$; - - : ovalbumin $(n=8) ; \quad$ : SR $48968+$ OA $(n=6) ;-\square-$ SR $140333+$ OA $(n=6)$. Significance of differences: saline vs OA, $\mathrm{p}<0.001$; OA vs SR 48968 $+\mathrm{OA}, \mathrm{p}<0.01 ; \mathrm{SR} 48968+\mathrm{OA}$ vs saline, Ns; OA vs SR $140333+$ OA, NS; SR 140333 + OA vs saline. (Reproduced, with permission, from [64]). 
In contrast, in another study, interleukin-8 (IL-8)induced bronchial hyperresponsiveness in the guineapig could not be reduced either by FK224 or FK888 [71]. In these conditions, the bronchial hyperresponsiveness induced by intranasal administration of IL- 8 was closely associated with recruitment of neutrophils, but not eosinophils, and involved thromboxane $\mathrm{A}_{2}\left(\mathrm{TxA}_{2}\right)$ as a main mediator [72]. Differences in the mechanisms of the development of bronchial hyperresponsiveness in the various experimental models of bronchopulmonary alterations in the guinea-pig could also explain the discrepancies between the effectiveness of tachykinin receptor antagonists. However, the results obtained with selective tachykinin $\mathrm{NK}_{2}$ receptor antagonists, such as SR 48968 and MEN 10,627, strongly suggest that tachykinins are involved in the development of airway hyperresponsiveness, and that tachykinin $\mathrm{NK}_{2}$ receptor stimulation plays an important role in this phenomenon, in the guineapig. It was reported that tachykinins are essential for the development of tracheal hyperreactivity induced by toluene diisocyanate in mouse airways [62]. In contrast to the prevention of airway hyperresponsiveness by the tachykinin $\mathrm{NK}_{2}$ receptor antagonist in guinea-pig, the hyperresponsiveness observed in the mouse was completely blocked by the tachykinin $\mathrm{NK}_{1}$ receptor antagonist, RP 67,580 [62].

Since the actions of tachykinins are terminated by proteolytic cleavage due mainly to neutral endopeptidase (NEP) E.C. 3.4.24.11, it has been proposed that this enzyme plays a regulatory role in the development of bronchial hyperresponsiveness and airway inflammation. Blockade of NEP by phosphoramidon potentiates airway responses to exogenous and endogenous neuropeptides [73, 74]. Moreover, bronchial hyperresponsiveness to SP has been reported after viral infection or cigarette smoke exposure [75-78], which altered NEP activity. Furthermore, only guinea-pigs pretreated with the NEP inhibitor, phosphoramidon, elicited a significant increase in airway response to $\mathrm{SP}$ after antigen challenge [79], and to acetylcholine (ACh) after SP or citric acid exposure $[49,53]$.

\section{Tachykinins and microvascular leakage}

Among the biological effects elicited by tachykinins, which might be involved in the alteration of pulmonary responses, microvascular leakage and the subsequent increase in plasma protein extravasation, a component of "neurogenic inflammation" might play an important role. Pharmacological control of vascular leakage may be of interest in asthma, because airway oedema contributes not only to airway narrowing but also to airway hyperresponsiveness [80]. Several studies have indicated that tachykinin $\mathrm{NK}_{1}$ receptors are involved in neurogenic inflammation in the central airways of guineapig and rat [81-83].

SP alone has been shown to induce microvascular leakage when administered intravenously $[84,85]$, or by aerosol [86], in various animal species, including guineapigs and rats. Hence, the activity of SP on microvascular leakage is potentiated by pretreatment of the guinea-pig with a NEP inhibitor [87]. It has been demonstrated that SP-induced plasma protein extravasation is mediated mainly through tachykinin $\mathrm{NK}_{1}$ receptor stimulation.
Indeed, in guinea-pig airways, the tachykinin $\mathrm{NK}_{1}$ receptor antagonist, CP 96,345, has been reported to reduce microvascular leakage induced by exogenous SP, capsaicin, electrical field stimulation (EFS) or bradykinin $[81,88]$. Inhalation of antigen by guinea-pigs leads to plasma extravasation of the trachea and nasal mucosa [83]. Interestingly, after an early phase of extravasation, release of neuropeptides from sensory nerves occurs, with subsequent increase in extravasation via activation of tachykinin $\mathrm{NK}_{1}$ receptors, as demonstrated by the inhibitory activity of CP 96,345 [83]. $\mathrm{NK}_{1}$ receptor stimulation has also been reported to be involved in the delayed-type hypersensitivity-induced increase in vascular permeability in the mouse small intestine [89], in the SP-induced inflammatory responses in guinea-pig skin [90] and in capsaicin-induced mouse ear oedema [91].

A role for tachykinin $\mathrm{NK}_{2}$ receptors in microvascular leakage cannot be excluded, since SR 48968 inhibited NKA-induced microvascular leakage in guinea-pigs [88]; however, NKA is considerably less potent and efficient than SP for inducing this effect. TOUSIGNANT et al. $[92]$ recently reported that $\left[\beta-\mathrm{Ala}^{8}\right] \mathrm{NKA}(4-10)$ may induce plasma protein extravasation in guinea-pig secondary bronchi and intraparenchymal airways, via tachykinin $\mathrm{NK}_{2}$ receptor stimulation.

We recently showed that aerosolized SP, in addition to its direct effects, potentiates histamine-induced microvascular leakage in phosphoramidon-pretreated guineapigs 24 h later [67]. In these conditions, SR 140333 has been shown to markedly reduce the SP-induced potentiation of microvascular leakage induced by histamine, whereas SR 48968 had no preventative effects [67]; strengthening the role of the tachykinin $\mathrm{NK}_{1}$ receptor in the microvascular leakage following tachykinin stimulation. Similar results were obtained in animals exposed to aerosolized citric acid and challenged $24 \mathrm{~h}$ later with histamine [93].

\section{Tachykinins and inflammatory cells}

Several effects of SP on inflammatory cells have been described [94]. For example, SP elicited granulocyte adhesion and infiltration in skin $[90,95]$. However, the infiltration of inflammatory cells appears to be mediated via the release of secondary mediators, possibly mast cell-derived mediators with 5-lipoxygenase products [90, 96].

Tachykinins have not been demonstrated to directly induce eosinophil chemotaxis in vivo [49] and in vitro [97], which suggests that SP-induced bronchial hyperresponsiveness is not closely related to eosinophil infiltration in airways [49]. Moreover, capsaicin or SR 48968 pretreatment prevented antigen challenge-induced airway hyperresponsiveness in sensitized guinea-pigs, but not the recruitment of eosinophils in airways [54, 55, 98]. Such data have recently been confirmed by VAN OOSTERHOUT et al. [50] studying the involvement of interleukin-5 (IL-5) and SP in the development of airway hyperreactivity to histamine in guinea-pigs. Indeed, in vivo administration of either IL-5 or SP induced the development of airway hyperreactivity, whereas administration of IL-5, but not SP, induced a significant increase in the number of eosinophils and eosinophil peroxidase 
activity in bronchoalveolar lavage (BAL) cells. Moreover, the simultaneous administration of IL-5 and SP did not potentiate the hyperreactivity and eosinophilia observed with IL-5 alone. These data suggest that IL-5 is important in the recruitment of eosinophils, whereas both IL-5 and SP are involved in the induction of airway hyperreactivity [50].

In rabbits immunized to Alternaria tenuis, chronic treatment with capsaicin induced a reduction of bronchial hyperresponsiveness, without inhibitory effect on the pulmonary recruitment of eosinophils and neutrophils [63]. In contrast, in primates, dual antagonism by tachykinin $\mathrm{NK}_{1}$ receptor antagonist $(\mathrm{CP} 99,994)$ plus tachykinin $\mathrm{NK}_{2}$ receptor antagonist (SR 48968) markedly reduced the eosinophil recruitment in BAL fluids induced by antigen challenge, whereas each antagonist used alone was ineffective [99]. More recently, KALTREIDER et al. [100] reported that the tachykinin $\mathrm{NK}_{1}$ receptor antagonist, CP 96,345, moderately, but significantly, reduced the total numbers of leucocytes, lymphocytes and granulocytes retrieved by BAL after antigen challenge of sensitized mice. This result suggests that tachykinins may be secreted locally during pulmonary immune responses, and are recognized by leucocytes infiltrating lung tissue [100].

Although few data are available on the activation of eosinophils by SP, KROEGEL et al. [101] demonstrated that SP can induce eosinophil peroxidase release from guinea-pig eosinophils. When eosinophils from allergic donors were pretreated with SP, the chemotactic responses to PAF or leukotriene $\mathrm{B}_{4}\left(\mathrm{LTB}_{4}\right)$ were enhanced [97]. Although SP is known to stimulate the chemotaxis of human monocytes [102] and rabbit neutrophils [103], a moderate chemotactic activity of SP on neutrophils both from healthy subjects and asthmatic patients has been observed [104]. Interestingly, SP- or interleukin 1 (IL1)-induced polymorphonuclear leucocyte accumulation was prevented by a tachykinin $\mathrm{NK}_{1}$ but not a $\mathrm{NK}_{2}$ receptor antagonist [105]. Furthermore, the release of endogenous tachykinins, possibly SP, may occur following IL-1 injection in vivo [105].

Tachykinins have other effects in vitro, including stimulation of human T- and B- lymphocytes and fibroblast proliferation [106-109]. Tachykinins may also modulate inflammatory cell activation through the release of various cytokines. Lotz et al. [110] reported that SP induced the release of IL-1, interleukin-6 (IL-6) and tumour necrosis factor- $\alpha$ (TNF- $\alpha$ ) from human monocytes. SP has also been demonstrated to release IL-8 from human polymorphonuclear leucocytes and to enhance the IL-8 release induced by other stimuli, such as N-formyl-methionyl-leucyl-phenylalanine (fMLP) [111]. Finally, in association with human T-lymphocyte proliferation, an increase in IL-2 messenger ribonucleic acid (mRNA) expression by SP has been reported by CALvo et al. [112].

The role of tachykinin $\mathrm{NK}_{1}$ receptors in tachykinininduced leucocyte activation in airways has recently been strengthened by the observation that the adhesion of leucocytes, induced in the venules of rat trachea by SP or capsaicin, can be reduced by a selective tachykinin $\mathrm{NK}_{1}$ receptor antagonist, $\mathrm{CP} 96,345$, and thus appears to be mediated by tachykinin $\mathrm{NK}_{1}$ receptors [113]. However, the role of tachykinin $\mathrm{NK}_{1}$ receptor stimulation in the neutrophil chemotaxis is not completely established, since the tachykinin $\mathrm{NK}_{2}$ receptor antagonist, SR 48968, has been found to inhibit tachykinin-induced chemotaxis of human neutrophils [114].

Bronchial hyperresponsiveness induced by aerosolized SP in phosphoramidon-pretreated guinea-pigs was described as not being associated with recruitment of granulocytes in the airways [49]. In contrast, an enhanced chemiluminescence and an increase in arachidonate release from alveolar macrophages of guinea pigs exposed to SP was observed, in comparison to alveolar macrophages of guinea-pigs pretreated only with phosphoramidon $[49,98]$. These results suggest an ex-vivo activation of alveolar macrophages by SP when administered by aerosol, since no alteration of the cell composition in the BAL was observed, which probably indirectly modifies the reactivity of macrophages through their phagocytic properties. SP also stimulates guinea-pig macrophages in vitro to induce the release of superoxide anions [115], through stimulation of tachykinin $\mathrm{NK}_{2}$ receptors and, to a lesser extent, tachykinin $\mathrm{NK}_{1}$ receptors [116]. Interestingly, this effect was enhanced in cells taken from antigen-sensitized guinea-pigs [117]. More recently, SP has been shown to induce gelatinase production by alveolar macrophages through tachykinin $\mathrm{NK}_{2}$ receptor activation [118]. In contrast, alveolar macrophages both from asthmatic patients and healthy subjects were only poorly or not activated at all by SP in vitro [119].

TAM et al. [120] reported that SP or EFS degranulate tracheal mast cells, contributing to the neurogenic responses in the trachea [120]. This result is consistent with the release of histamine by SP and capsaicin from guineapig airway mast cells [121]. Moreover, in these conditions, the mechanism of histamine release depends predominantly on the activation of tachykinin $\mathrm{NK}_{1}$ and $\mathrm{NK}_{2}$ receptors, as suggested by the inhibition of SPinduced histamine release both by tachykinin $\mathrm{NK}_{1}$ and $\mathrm{NK}_{2}$ receptor blockade [121]. In contrast, HuA et al. [122] reported that SP may increase sensitivity of mast cells to EFS-discharged mediators or facilitate the release of mast cell-stimulating mediators from autonomic nerves, rather than a direct stimulating effect of SP on mast cell degranulation, as previously suggested by DEVILLIER et al. [30] and Mously et al. [123]. However, the stimulation of mast cells by SP may strongly contributes to the airway effects of tachykinins.

\section{Influence of inflammatory mediators on tachykinin responses}

In addition to their direct activity on the airways, many inflammatory mediators may influence the responses of various tachykinins. It was previously demonstrated, in anaesthetized dog, that histamine administered by aerosol induced an increase in the activity of C-fibres [37]. Antigen challenge induced an enhancement of noncholinergic contractile response to vagus nerves and EFS in guinea-pig isolated trachea [124], or the response to SP in the isolated airways of immunized rabbits [125]. In addition, prostaglandin $\mathrm{E}_{2}\left(\mathrm{PGE}_{2}\right)$, an inflammatory mediator derived from the cyclo-oxygenase pathway of arachidonic acid metabolism, enhanced the pulmonary chemoreflex (apnoea, bradycardia and hypotension) [36], 
and has been shown to increase the sensitivity of the capsaicin-induced cough reflex in healthy human volunteers [126]. Furthermore, high doses of $\mathrm{PGE}_{2}$, administered either by inhalation or injection, can stimulate bronchopulmonary C-fibre endings [127, 128]. Similarly, $\mathrm{LTD}_{4}$ has been shown to cause the release of SP from guinea-pig isolated trachea, or to potentiate the tachykinin-mediated response in the guinea pig isolated airways evoked by the threshold electrical stimulation of the vagus nerve or EFS [129, 130]. In Fisher (F344) rats, tachykinins cause bronchoconstriction and extravasation of plasma protein by indirect mechanisms involving the activation of tachykinin $\mathrm{NK}_{1}$ receptors, release of serotonin (5-HT) and mast cell activation [29, 131]. Recently, tachykinins have been reported to be involved in KCl-induced contraction of guinea-pig trachea [132]. Finally, bradykinin may also be involved in the effects of tachykinin, since Fox et al. [38] reported that bradykinin caused sensitization of airway sensory nerves and an enhancement of the cough reflex in conscious guineapigs [38].

Change in afferent innervation and tachykinin receptor expression in the airway: correlation with airway hyperresponsiveness

Various studies have suggested that following the inflammatory process, the electrical stimulation of afferent fibres is markedly modified, tachykinin synthesis by these nerves is increased, and tachykinin receptor expression may be enhanced. Indeed, using sensitized guineapigs, Riccio and co-workers [133, 134] reported an approximative fourfold increase of the mechanical sensitivity of $\mathrm{A} \delta$ afferent fibres following exposure to antigen. Moreover, chronic airway inflammation after allergen challenge in the guinea-pig increases excitatory NANC nerve function, possibly by enhancing sensory neuro-peptide production and/or release [124, 135]. An increase in the synthesis of tachykinins from these fibres was demonstrated by FISCHER et al. [4], following the inflammatory process of the airways after allergic reaction. In this study, $24 \mathrm{~h}$ after allergen exposure in sensitized guinea-pigs, there was a three- to fourfold enhancement of tissue concentrations of NKA, SP and CGRP in the lung, but not in the trachea. An increase in local tachykinin synthesis was not demonstrated, but neuropeptides measured in the lung were probably synthesized in the cell bodies of neurons located outside the lung, and then passed into the organ via axonal transport [4]. These authors also observed that $12 \mathrm{~h}$ after antigen stimulation, preprotachykinin mRNA was increased by $20 \%$ in nodose ganglions, but they did not detect significant quantitative changes in jugular ganglions, which was surprising, since nodose ganglions do not send tachykinincontaining axons to the airways in healthy animals.

An increase in receptor synthesis and/or expression has also been reported in rats in a model of chronic inflammatory disease produced by Mycoplasma pulmonis infection [136, 137]. In this study, the rat airways infected with $M$. pulmonis became abnormally sensitive to tachykinin, as revealed by the increase in plasma leakage evoked by exposure to SP. Using an antibody to rat tachykinin $\mathrm{NK}_{1}$ receptor, BALUK et al. [138] demonstrated a dramatic increase in the number of tachykinin $\mathrm{NK}_{1}$ receptors of endothelial cells, of postcapillary venules, and of new capillary-size vessels following inflammatory reaction due to $M$. pulmonis infection. These results suggest that synthesis of tachykinins undergoes marked change in the development of inflammation. Similar results have been obtained in other organs, such as skin [139]. MCCARSON and KRAUSE [140] demonstrated that tachykinin $\mathrm{NK}_{1}$ and $\mathrm{NK}_{3}$ receptor mRNA expression in the rat spinal cord dorsal horn is increased during adjuvant or formalin-induced nociception.

\section{Tachykinins and asthma}

Whilst there appears to be convincing evidence that sensory nerves and the subsequent tachykinin release play a role in bronchial hyperresponsiveness in various animal models, is there any evidence that sensory nerves play a role in asthma? In asthmatic subjects, SP exposure enhanced, maximal airway narrowing to methacholine $24 \mathrm{~h}$ later [52]. In allergic rhinitis, tachykinins partially mimicked the immediate nasal response to antigen by inducing nasal obstruction, recruitment of polymorphonuclear cells and leakage of albumin [141]. Immunohistochemical studies revealed conflicting evidence of an increase in SP-containing nerves in asthma [142-144]. Using high performance liquid chromatography, a reduction in SP-like immunoreactivity was observed in central airways of subjects who died of asthma or who were undergoing thoracotomy, compared with age-matched, nondiseased subjects [145]. Because of the rapid enzymatic cleavage in the extracellular microenvironment, the tissue content of neuropeptides reflects a balance between synthesis and release. In this condition, SP may be released during a severe asthmatic episode, and may then rapidly be degraded and not detected by the immunoassay [145]. This is consistent with an increase in SP-like immunoreactivity detected in the BAL fluid [146] and sputum [147] of asthmatics. This would suggest that neuropeptides can be released within the airway wall and, depending on the degree of stimulation, lead to a reduction in neuropeptide tissue content.

Recently, studies have documented possible changes in neurokinin receptor expression in asthma. There appears to be an increase in mRNA transcripts for tachykinin $\mathrm{NK}_{1}$ [148] and $\mathrm{NK}_{2}$ [149] receptors in lung tissue from asthmatics compared with nonasthmatics. The local release of neuropeptides may induce neuropeptide receptor tachyphylaxis that leads to increased synthesis of mRNA transcripts for these receptors. However, evidence of an increase in the expression of neuropeptide mRNA in sensory nerves and/or an increase in afferent activity awaits documentation in humans. Finally, it is also evident that several drug classes already in therapeutic use may interfere with sensory nerve function [150].

\section{Tachykinins and cough}

\section{Involvement of tachykinins in cough}

The involvement of C-fibre receptors in cough is based on experiments with capsaicin or with citric acid which 
can both stimulate pulmonary and bronchial C-fibre receptors [45, 151-154]. When given by aerosol, capsaicin and citric acid are powerful tussigenic agents in humans and other animals, and are now used as standard methods to study cough in preclinical and clinical studies [155]. Other examples showing that $\mathrm{C}$-fibre receptor activation may cause cough were reported by FORSBERG et al. [153], who studied cough induced in guinea-pigs by inhalation of citric acid, by capsaicin, nicotine and mechanical stimulation of the trachea. Administration of large doses of capsaicin blocked the cough reflex due to citric acid and capsaicin, but not that due to nicotine and mechanical stimulation [153]. These authors concluded that the first two stimuli (citric acid and capsaicin) acted via receptors and the last two (nicotine and mechanical stimulation) via RARs. However, as suggested by WIDDICOMBE [40], capsaicin is probably not very specific and selective for C-fibre, and can stimulate RARs leading to cough $[156,157]$. In addition, large doses of capsaicin can damage or destroy A $\delta$ myelinated fibres as well as C-fibres [158]. In contrast, due to peripheral and central nervous interactions, stimulation of C-fibres may inhibit cough in some circumstances [40].

Controversial reports have proposed tachykinins as tussive agents by themselves in guinea-pigs [159-161]. In humans, SP aerosols given to healthy subjects or to patients with asthma did not cause cough, but evoked a sensation of tightness in the chest of asthmatics, possibly secondary to bronchoconstriction, indicating that some sensory nerves were being stimulated [162]. In another study, SP aerosols caused cough in patients with upper airway infection but not in healthy subjects [163].

However, if tachykinins do not induce cough, they can elicit a marked sensitizing effect on the cough reflex, through enhanced activation of RARs. Such an action was first established by recordings of single fibres from RARs in rabbits by PRABHAKAR et al. [164], who showed that systemic SP not only caused reflex changes characteristic of stimulation of lung RARs but also increased the impulse frequency in vagal single fibres coming from RARs. This has recently been confirmed by Fox et al. [161], who reported that SP, when given by aerosol at concentrations up to $100 \mu \mathrm{M}$ in the presence of the peptidase inhibitors, phosphoramidon and captopril, did not evoke cough by itself. In electrophysiological studies, SP applied directly onto receptive fields in the trachea did not activate either single Cfibres or A $\delta$-fibres. In contrast, prior exposure of guineapigs to SP $(10 \mathrm{nM})$ markedly enhanced citric acid-induced cough.

In guinea-pigs, chronic treatment with the angiotensinconverting enzyme (ACE) inhibitor, captopril, added to drinking water and given for 2 weeks, can induce an enhancement of citric acid-induced cough [165]. This effect appears to be mediated via an accumulation of bradykinin, since the bradykinin $\mathrm{B}_{2}$ receptor antagonist, Hoe 140 (Icatibant) inhibits this potentiation [166]. It was proposed that the effect of bradykinin was likely to be due to $\mathrm{C}$-fibre sensitization and/or to a release of tachykinins [166-168].

When given by aerosol, bradykinin, in the presence of phosphoramidon and captopril, led to a marked increase in citric acid-induced cough response; and when used in in vitro studies, bradykinin produced an increase of 100$400 \%$ in the firing of single vagal C-fibres stimulated by capsaicin $[165,169]$. Interestingly, patients treated with ACE inhibitors developed cough, and cough response to capsaicin was enhanced in these patients [170]. Finally, cough sensitivity to capsaicin in humans increases during viral infections [171].

\section{Effects of tachykinin receptor antagonists in cough}

The view that tachykinins are involved in cough is also supported by the observation that tachykinin antagonists block cough in several experimental conditions. The antitussive effect of tachykinin $\mathrm{NK}_{2}$ receptor antagonists has been clearly demonstrated, but the effect of tachykinin $\mathrm{NK}_{1}$ receptor antagonists is still debated. Indeed, SR 48968 inhibits, in a dose-dependent manner, citric acid- [172-174] or capsaicin- [175] induced cough in the unanaesthetized guinea-pig. This compound is approximately 150 times more potent than codeine and, in contrast to the latter, the effect of SR 48968 is not inhibited by naloxone [172]. It must be noted that both SR 48968 and codeine exert only a partial inhibition of the cough response (approximately 60-70\%) [172-174]. The inhibitory effect of SR 48968 is not dependent on the reduction of citric acid-induced bronchoconstriction, since in guinea-pigs pretreated with bronchodilator doses of salbutamol, which did not reduce cough, the effect of SR 48968 was still present [173]. Moreover, a dissociation between cough and bronchoconstriction has been clearly demonstrated by FORSBERG et al. [176], who, in agreement with FULLER and COLLIER [177] and JACKSON [178], have shown that sodium cromoglycate inhibited bronchoconstriction, but not citric acid-induced cough, whereas lidocaine inhibited cough but not bronchoconstriction. The antitussive effect of tachykinin $\mathrm{NK}_{2}$ receptor antagonists has also been shown with the compound MEN 10627 against cough induced by allergen challenge in guinea-pigs sensitized with ovalbumin [179]. However, Fox et al. [161] did not observe any effect of SR 48968 on cough induced by citric acid in the guineapig, and LALLOO et al. [166] observed only a nonsignificant reduction.

Regarding the effect of tachykinin $\mathrm{NK}_{1}$ antagonists, various studies have shown no inhibitory activity. Such results were reported using 140333 [173] or CP 99,994 [161] on citric acid-induced cough in the guinea-pig. Similar observations have been reported in asthmatic patients using CP 99,994 against cough induced by inhalation of saline (increased osmolarity) [180]. In contrast, UjIIE et al. [181] and YASUMITSU et al. [174] reported that FK 888, an antagonist of tachykinin $\mathrm{NK}_{1}$ receptors, inhibited cough induced by phosphoramidon, tobacco smoke, SP or citric acid. The reason for this discrepancy is unclear. Recent pharmacological and biochemical studies have suggested that two isoforms or two subtypes of the tachykinin $\mathrm{NK}_{1}$ receptor could exist [182-184]. One hypothesis proposes that one isoform or subtype of the tachykinin $\mathrm{NK}_{1}$ receptor, to which some tachykinin $\mathrm{NK}_{1}$ receptor antagonists could bind with higher affinity, would be implicated in cough control. Both GiRARD et al. [173] and YASUMITSU et al. [174] have observed that tachykinin $\mathrm{NK}_{1}$ receptor antagonists, SR 140333 and FK 888, were able to potentiate the effect of SR 48968, in terms of maximal effect. 
The question of a central or peripheral effect for the inhibitory activity of tachykinin antagonists is not clear, since central administration of these antagonists was not performed. Yasumitsu et al. [174] have, however, suggested that the effects of the tachykinin $\mathrm{NK}_{1}$ receptor antagonist, FK 888, could be attributed to its peripheral action. Indeed, intracerebroventricular (i.c.v) injection of a tachykinin $\mathrm{NK}_{1}$ receptor agonist induced foot-tapping in gerbils, which could be inhibited by the central nervous system-penetrant tachykinin $\mathrm{NK}_{1}$ receptor antagonist, CP 99,994 [185], but not by a nonpenetrant tachykinin $\mathrm{NK}_{1}$ receptor antagonist [186]. The fact that FK 888 did not inhibit SP (i.c.v. injection)-induced foottapping in gerbils even at $10 \mathrm{mg} \cdot \mathrm{kg}^{-1}$ i.v., might suggest that this compound may penetrate only poorly into the central nervous system, but did not exclude a possible central effect for other compounds [174].

A possible interaction between RARs and C-fibre receptors proposed by WIDDICOMBE [40] suggests a new hypothesis for the mechanism of action of tachykinin antagonists. As discussed above, activation of RARs induces cough reflex, and stimulation of C-fibres with a release of tachykinin that leads to the facilitation of nerve transmission associated with RAR stimulation. This explains why tachykinins, and especially SP, are only moderate tussive agents or may have no action at all, but dramatically potentiate cough induced by citric acid. It is also suggested that citric acid and capsaicin act both on RARs and C-fibre receptors, and are efficient inducers of cough through the activation of RARs, but this was observed through the increased stimulation of C-fibre receptors. This might explain the partial inhibition of the effects of tachykinin antagonists on citric acid-induced cough [172-174], since these compounds inhibit the effect of tachykinins released by C-fibres but do not alter the stimulation of RARs. Therefore, tachykinin antagonists interact with the amplification phenomenon induced by citric acid. The same observation could apply to the inhibitory activity of codeine, since it was previously described as an inhibitor of tachykinin release [187, 188].

The sensitizing effect of C-fibre on the activation of RARs is also suggested by the experiments of LALLOO et al. [166], who showed that SR 48968 moderately reduced citric acid-induced cough in guinea-pigs, but abolished the enhancement of citric acid-induced cough caused by exposure to ozone at $1 \mathrm{ppm}$ for $3 \mathrm{~h}$.

\section{Conclusion}

The mechanism of the development of bronchial hyperresponsiveness is unclear. It is generally accepted that pulmonary inflammation, mainly associated with a recruitment of inflammatory cells and increased release of inflammatory mediators inducing bronchoconstriction and plasma protein extravasation, plays a key role in the development of bronchial hyperresponsiveness [34, 189]. However, SP-induced airway hyperresponsiveness in the guinea-pig is not associated with eosinophil infiltration in the lung tissue [49], suggesting a dissociation between recruitment of inflammatory cells in the airways and bronchopulmonary alterations, as was previously observed for antigen-induced bronchial hyperresponsiveness [190-192]. Furthermore, it is also of interest that the eosinophilia associated with bronchial hyperresponsiveness induced by PAF or allergen was not inhibited by capsaicin [63, 193]. Hence, exposure of phosphoramidonpretreated guinea-pigs to SP is followed by an increase in superoxide anion production and arachidonate release by alveolar macrophages, suggesting that these cells may play a key role in the development of bronchial hyperresponsiveness induced by SP $[49,98]$. SP also induced an increase in microvascular leakage, allowing the plasma protein extravasation which may be involved in the bronchopulmonary alterations following allergic reaction [189].

The present review suggests a specialization of tachykinin $\mathrm{NK}_{1}$ versus tachykinin $\mathrm{NK}_{2}$ receptors in mediating the development of microvascular leakage hypersensitivity versus development of airway hyperresponsiveness by exposure to SP or citric acid in guinea-pigs. Whether or not the same situation applies exactly to human airways is not known, although it is suggested by some results. Thus, only tachykinin $\mathrm{NK}_{2}$ receptors mediate contraction of human isolated airways [194], and NKA, but not SP, produces bronchoconstriction in asthmatics [162]. Moreover, in allergic rhinitis, tachykinins induce nasal obstruction mainly through tachykinin $\mathrm{NK}_{1}$ receptor activation, whereas albumin leakage and recruitment of inflammatory cells probably involve tachykinin $\mathrm{NK}_{1}$ and $\mathrm{NK}_{2}$ receptors [141]. This suggests that an antagonist with mixed (and possibly balanced) affinity for tachykinin $\mathrm{NK}_{1}$ and $\mathrm{NK}_{2}$ receptors could be of interest in a wide investigation of the various components of airway hyperresponsiveness and possible associations with pulmonary inflammation. Joos et al. [195] recently reported that the dual antagonist FK224 did not offer protection against NKA-induced bronchoconstriction in a group of mild asthmatic patients. Since FK224 is a moderate tachykinin receptor antagonist and was used at doses that did not displace concentration-response curves of NKA in asthmatics, further studies have to be conducted with selective antagonists to provide a final statement on the therapeutic interest of such compounds. SR 48968 might be a candidate, since it has been reported to be able to displace concentration-response curves in asthmatics [196]. The question of a role of tachykinin $\mathrm{NK}_{1}$ and $\mathrm{NK}_{2}$ receptors will have to be further reconsidered, since it was recently reported that the tachykinin $\mathrm{NK}_{3}$ receptor antagonist, SR 142801, markedly reduced the bronchial hyperresponsiveness and the increased microvascular leakage after exposure of guinea-pigs to SP [12].

Thus, taken together, the results obtained with the various selective receptor antagonists provide pharmacological evidence that tachykinins play a role in delayed bronchopulmonary alterations and suggest that tachykinin receptor antagonists may be useful for investigating mechanisms and possibly reducing airway functional alterations in asthmatic patients.

Acknowledgement: The authors thank G. Bouër for his assistance in preparing the manuscript.

\section{References}

1. Lembeck F, Holzer P. Substance P as neurogenic mediator of antidromic vasodilation and neurogenic plasma 
extravasation. Naunyn Schmiedebergs Arch Pharmacol 1970; 310: 175-183.

2. Lundberg JM, Saria A. Polypeptide-containing neurons in airway smooth muscle. Ann Rev Physiol 1987; 49: 557-572.

3. Ellis JL, Undem BJ. Pharmacology of nonadrenergic noncholinergic nerves in airway smooth muscle. Pulm Pharmacol 1994; 7: 205-223.

4. Fischer A, McGregor GP, Saria A, Philippin B, Kummer $\mathrm{W}$. Induction of tachykinin gene and peptide expression in guinea-pig nodose primary afferent neurons by allergic airway inflammation. J Clin Invest 1996; 98: 2284-2291.

5. Lundberg JM. Pharmacology of co-transmission in the autonomic nervous system: integrative aspects on amines, neuropeptides, adenosine triphosphate, amino acids and nitric oxide. Pharmacol Rev 1996; 48: 113-178.

6. Guard S, Watson SP. Tachykinin receptor types: classification and membrane signalling mechanisms. Neurochem Int 1991; 18: 149-165.

7. Frossard N, Advenier C. Tachykinin receptors and the airways. Life Sci 1991; 49: 1941-1953.

8. Maggi CA. Tachykinin receptors and airway pathophysiology. Eur Respir J 1993; 6: 735-742.

9. Baluk P, Bunnett NW, McDonald DM. Localization of tachykinin NK-1, NK-2 and NK-3 receptors in airways by immunohistochemistry. Am J Respir Crit Care Med 1996; 153: A161.

10. Buell G, Schulz MF, Arkinstall SJ, et al. Molecular characterisation, expression and localisation of human neurokinin-3 receptor. FEBS Lett 1992; 299: 90-95.

11. Myers A, Undem B. Electrophysiological effects of tachykinins and capsaicin on guinea-pig bronchial parasympathetic ganglion neurones. J Physiol 1993; 470: 665-679.

12. Advenier C, Daoui S, Cui YY, Lagente V, Emonds-Alt $\mathrm{X}$. Inhibition by the tachykinin $\mathrm{NK}_{3}$ receptor antagonist, SR 142801, of substance P-induced microvascular leakage hypersensitivity and airway hyperresponsiveness in guinea-pigs. Am J Respir Crit Care Med 1996; 153: A163.

13. Snider RM, Constantine JW, Lowe III JA, et al. A potent nonpeptide antagonist of the substance $\mathrm{P}$ (NK-1) receptor. Science 1991; 251: 435-437.

14. Garret C, Carruette A, Fardin V, et al. Pharmacological properties of a potent and selective nonpeptide substance P antagonist. Proc Natl Acad Sci USA 1991; 88: 10208-10211.

15. Fujji T, Murai M, Morimoto H, et al. Pharmacological profile of a high affinity dipeptide $\mathrm{NK}_{1}$ receptor antagonist, FK 888. Br J Pharmacol 1992; 107: 785-789.

16. Emonds-Alt X, Doutremepuich JD, Heaulme M, et al. In vitro and in vivo biological activities of SR 140333, a novel potent nonpeptide tachykinin $\mathrm{NK}_{1}$ receptor antagonist. Eur J Pharmacol 1993; 250: 403-413.

17. Gitter BD, Bruns RF, Howbert JJ, et al. Pharmacological characterization of LY303870: a novel, potent and selective nonpeptide substance $\mathrm{P}$ (neurokinin-1) receptor antagonist. Br J Pharmacol 1995; 275: 737-744.

18. Beattie DT, Beresford IJM, Connor HE, et al. The pharmacology of GR203040, a novel, potent and selective nonpeptide tachykinin $\mathrm{NK}_{1}$ receptor antagonist. $\mathrm{Br} J$ Pharmacol 1995; 116: 3149-3157.

19. Maggi CA, Giuliani S, Ballati L, et al. In vivo evidence for tachykininergic transmission using a new $\mathrm{NK}_{2}$ receptor selective antagonist, MEN 10,376. J Pharmacol Exp Ther 1991; 257: 1172-1178.
20. Emonds-Alt X, Vilain P, Goulaouic P, et al. A potent and selective nonpeptide antagonist of the neurokinin A $\left(\mathrm{NK}_{2}\right)$ receptor. Life Sci 1992; 50: PL101-PL106.

21. Advenier C, Rouissi N, Nguyen QT, et al. Neurokinin A $\left(\mathrm{NK}_{2}\right)$ receptor revisited with SR 48968, a potent nonpeptide antagonist. Biochem Biophys Res Commun 1992; 184: 1418-1424.

22. Maggi CA, Astolfi M, Giuliani S, et al. MEN 10,627, a novel polycyclic peptide antagonist of tachykinin $\mathrm{NK}_{2}$ receptors. J Pharmacol Exp Ther 1994; 271: 14951500.

23. Ball DI, Beresford IJM, Wren GPA, et al. In vitro and in vivo pharmacology of the nonpeptide antagonist at tachykinin $\mathrm{NK}_{2}$-receptors, GR159897. Abstract. $\mathrm{Br} \mathrm{J}$ Pharmacol 1994; 112: 48P.

24. Emonds-Alt X, Bichon D, Ducoux JP, et al. SR 142801, the first potent nonpeptide antagonist of tachykinin $\mathrm{NK}_{3}$ receptor. Life Sci 1994; 56: PL27-PL32.

25. Murai M, Moromoto H, Maeda Y, Kiyotoh S, Nishikawa M, Fujii T. Effect of FK 224, a novel compound $\mathrm{NK}_{1}$ and $\mathrm{NK}_{2}$ receptor antagonist, on airway constriction and airway edema induced by neurokinins and sensory stimulation in guinea-pigs. J Pharmacol Exp Ther 1992; 261: 403-408.

26. Robineau P, Longchampt $\mathrm{M}$, Kucharczyk N, et al. In vitro and in vivo pharmacology of S.16474, a novel dual tachykinin $\mathrm{NK}_{1}$ and $\mathrm{NK}_{2}$ receptor antagonist. Eur $J$ Pharmacol 1995; 294: 677-684.

27. Kudlacz EM, Shatzer SA, Knippenberg RW, et al. In vitro and in vivo characterization of MDL 105,212A, a nonpeptide NK-1/NK-2 tachykinin receptor antagonist. J Pharmacol Exp Ther 1996; 277: 840-851.

28. Regoli D, Boudon A, Fauchère JL. Receptors and antagonists for substance P and related peptides. Pharmacol Rev 1994; 46: 551-599.

29. Joos GF, Lefebvre RA, Kips JC, Pauwels RA. Tachykinins contract trachea from Fischer 344 rats by interaction with a tachykinin $\mathrm{NK}_{1}$ receptor. Eur J Pharmacol 1994; 271: 47-54.

30. Devillier P, Renoux M, Giroud JP, Regoli D. Peptides and histamine release from rat peritoneal mast cells. Eur J Pharmacol 1985; 117: 89-96.

31. Boushey HA, Holtzman MJ, Sheller JR, Nadel JA. Bronchial hyperreactivity. Am Rev Respir Dis 1980; 121: 389-413.

32. O'Byrne PM. Allergen-induced airway hyperresponsiveness. J Allergy Clin Immunol 1988; 81: 119-127.

33. Barnes PJ. New concepts in the pathogenesis of bronchial hyperresponsiveness and asthma. J Allergy Clin Immunol 1989; 83: 1013-1026.

34. Holgate ST, Djukanovic R, Wilson J, Roche W, Howarth $\mathrm{PH}$. Inflammatory processes and bronchial hyperresponsiveness. Clin Exp Allergy 1991; 21 (Suppl. 1): 30-36.

35. Bozic CR, Lu B, Höpken UE, Gerard C, Gerard NP. Neurogenic amplification of immune complex inflammation. Science 1996; 273: 1722-1725.

36. Lee LY, Morton RF. Pulmonary chemoreflex sensitivity is enhanced by prostaglandin $\mathrm{E}_{2}$ in anaesthetized rats. J Appl Physiol 1995; 79: 1679-1686.

37. Lee LY, Morton RF. Histamine enhances vagal pulmonary C-fiber responses to capsaicin and lung inflation. Respir Physiol 1993; 93: 83-96.

38. Fox AJ, Lalloo UG, Belvisi MG, Bernareggi M, Chung KF, Barnes PJ. Bradykinin-evoked sensitization of airway sensory nerves: a mechanism for ACE-inhibitor cough. Nature Med 1996; 2: 815-817. 
39. Hay DWP, Torphy TJ, Undem BJ. Cysteinyl leukotrienes in asthma: old mediators up to new tricks. Trends Pharmacol Sci 1995; 6: 304-339.

40. Widdicombe JG. Neurophysiology of the cough reflex. Eur Respir J 1995; 8: 1193-1202.

41. Widdicombe JG. Receptors in the trachea and bronchi of the cat. J Physiol 1954; 123: 71-104.

42. Widdicombe JG. Sensory innervation of the lungs and airways. In: Cervero F, Morrison JFB, eds. Progress in Brain Research. Vol. 67. Visceral Sensation. Amsterdam, Elsevier, 1986; pp. 49-64.

43. Das RM, Jeffery PK, Widdicombe JG. The epithelial innervation of the lower respiratory tract of the cat. $J$ Anat 1978; 126: 123-131.

44. Coleridge HM, Coleridge JCG. Reflex evoked from the tracheobronchial tree and lungs. In: Cherniack NS, Widdicombe JG, eds. Handbook of Physiology. 3. The Respiratory System. Vol. II. Control of Breathing. Bethesda, American Physiological Society, 1986; pp. 395-429.

45. Lundberg JM, Hokfelt T, Martling CR, Saria A, Cuello C. Substance P immunoreactive sensory nerves in the lower respiratory tract of various mammals including man. Cell Tissue Res 1984; 235: 251-261.

46. Omini C, Brunelli G, Hernandez A, Daffonchio L. Bradykinin and substance $\mathrm{P}$ potentiate acetylcholineinduced bronchospasm in guinea-pig. Eur J Pharmacol 1989; 163: 195-197.

47. Umeno E, Hirose T, Nishima S. Pretreatment with aerosolized capsaicin potentiates histamine-induced bronchoconstriction in guinea-pigs. Am Rev Respir Dis 1992; 146: $159-162$.

48. Hsuie T, Garland A, Ray DW, Hershenson MB, Leff AR, Solway J. Endogenous sensory neuropeptide release enhances nonspecific airway responsiveness in guineapigs. Am Rev Respir Dis 1992; 146: 148-153.

49. Boichot E, Lagente V, Paubert-Braquet M, Frossard N. Inhaled substance $\mathrm{P}$ induces activation of alveolar macrophages and increases airway responses in the guineapig. Neuropeptides 1993; 25: 307-313.

50. Van Oosterhout AJM, van Ark I, Hofman G, Van der Linde HJ, Fattah D, Nijkamp FP. Role of interleukin-5 and substance $\mathrm{P}$ in development of airway hyperreactivity to histamine in guinea-pigs. Eur Respir J 1996; 9: 493-499.

51. Tamura G, Sakai K, Taniguchi Y. Neurokinin A-induced bronchial hyperresponsiveness to methacholine in Japanese monkeys. J Exp Med 1989; 159: 69-73.

52. Cheung D, Van Der Veen H, Den Hartig J, Dijkmann JH, Sterk PJ. Effects of inhaled substance P on airway hyperresponsiveness to methacholine in asthmatic subjects in vivo. J Appl Physiol 1994; 77: 1325-1332.

53. Girard V, Yavo JC, Emonds-Alt X, Advenier C. The tachykinin $\mathrm{NK}_{2}$ receptor antagonist, SR 48968, inhibits citric acid-induced airway hyperresponsiveness in guineapigs. Am J Respir Crit Care Med 1996; 153: 1496-1502.

54. Matsuse T, Thomson RJ, Chen XR, Salari H, Schellenberg RR. Capsaicin inhibits airway hyperresponsiveness but not lipoxygenase activity or eosinophilia after repeated aerosolized antigen in guinea-pigs. Am Rev Respir Dis 1991; 144: 366-372.

55. Ladenius AR, Nijkamp FP. Capsaicin-pretreatment of guinea-pigs in vivo prevents ovalbumin-induced tracheal hyperreactivity in vitro. Eur J Pharmacol 1993; 235: 127-131.

56. Sheppard D, Scypinski L. A tachykinin receptor antagonist inhibits and an inhibitor of tachykinin metabolism potentiates toluene diisocyanate-induced airway hyper- responsiveness in guinea-pigs. Am Rev Respir Dis 1988; 138: 547-551.

57. Jarreau PH, D'Ortho MP, Boyer V, Harf A, MacquinMavier I. Effects of capsaicin on the airway responses to inhaled endotoxin in the guinea-pig. Am J Respir Crit Care Med 1994; 149: 128-133.

58. Perretti F, Manzini S. Activation of capsaicin-sensitive sensory fibers modulates PAF-induced bronchial hyperresponsiveness in anaesthetized guinea-pigs. Am Rev Respir Dis 1993; 148: 927-931.

59. Ladenius AR, Folkerts G, Van der Linde HJ, Nijkamp FP. Viral respiratory infection potentiates ovalbumininduced guinea-pig tracheal hyperresponsiveness: role of tachykinins. Br J Pharmacol 1995; 115: 1048-1052.

60. Koto H, Aizawa H, Takata S, Inoue H, Hara N. An important role of tachykinins in ozone-induced airway hyperresponsiveness. Am Rev Respir Crit Care Med 1995; 151: 1763-1769.

61. Buckley TL, Nijkamp FP. Airways hyperreactivity and cellular accumulation in a delayed-type hypersensitivity reaction in the mouse: modulation by capsaicin-sensitive nerves. Am J Respir Crit Care Med 1994; 149: 400-407.

62. Scheerens H, Buckley TL, Muis T, Van Loveren H, Nijkamp FP. The involvement of sensory neuropeptides in toluene diisocyanate-induced tracheal hyperreactivity in the mouse airways. $B r J$ Pharmacol 1996; 119: $1665-1671$.

63. Herd CM, Gozzard N, Page CP. Capsaicin pretreatment prevents the development of antigen-induced airway hyperresponsiveness in neonatally immunised rabbits. Eur J Pharmacol 1995; 282: 111-119.

64. Boichot E, Germain N, Lagente V, Advenier C. The tachykinin $\mathrm{NK}_{2}$ receptor antagonist, SR 48968, prevents substance P-induced airway hyperresponsiveness in guinea-pigs. Br J Pharmacol 1995; 114: 259-261.

65. Kudlacz EM, Knippenberg RW, Logan DE, Burkolder TP. Effect of MDL 105,212, a nonpeptide $\mathrm{NK}_{1} / \mathrm{NK}_{2}$ receptor antagonist, in an allergic guinea-pig model. $J$ Pharmacol Exp Ther 1996; 279: 732-739.

66. Mizuguchi M, Fujimara M, Amemiya T, Nishi K, Ohka $\mathrm{T}$, Matsuda $\mathrm{T}$. Involvement of $\mathrm{NK}_{2}$ receptors rather than $\mathrm{NK}_{1}$ receptors in bronchial hyperrresponsiveness induced by allergic reaction in guinea-pigs. Br J Pharmacol 1996; 117: 443-448.

67. Boichot E, Biyah K, Germain N, Emonds-Alt X, Lagente $\mathrm{V}$, Advenier C. Involvement of tachykinin $\mathrm{NK}_{1}$ and $\mathrm{NK}_{2}$ receptors in substance P-induced microvascular leakage hypersensitivity and airway hyperresponsiveness in guinea-pigs. Eur Respir J 1996; 9: 1445-1450.

68. Yoshihara S, Geppetti P, Linden A, Hara M, Chan B, Nadel JA. Tachykinins mediate the potentiation of antigen-induced bronchoconstriction by cold air in guineapigs. J Allergy Clin Immunol 1996; 97: 756-760.

69. Perretti F, Ballati L, Manzini S, Maggi CA, Evangelista S. Antibronchospastic activity of MEN 10,627, a novel tachykinin $\mathrm{NK}_{2}$ receptor antagonist, in guinea-pig airways. Eur J Pharmacol 1995; 273: 129-135.

70. Tocker JE, Gertner SB, Welton AF, Selig WM. Vagal stimulation augments pulmonary anaphylaxis in the guinea-pig lung. Am J Respir Crit Care Med 1995; 151 : 461-469.

71. Fujimura M, Tsujiura M, Nomura M, Mizuguchi M, Matsuda T, Matsushima K. Sensory neuropeptides are not directly involved in bronchial hyperresponsiveness induced by interleukin- 8 in guinea-pigs in vivo. Clin Exp Allergy 1996; 26: 357-362. 
72. Xiou Q, Fujimura M, Nomura M, et al. Bronchial hyperresponsiveness and airway neutrophil accumulation induced by interleukin- 8 and the effects of thromboxane $\mathrm{A}_{2}$ antagonist, S-1452, in guinea-pigs. Clin Exp Allergy 1995; 25: 51-59.

73. Stimler-Gerard NP. Neutral endopeptidase-like enzyme controls the contractile activity of substance $\mathrm{P}$ in guineapig lung. J Clin Invest 1987; 79: 1819-1825.

74. Thompson JE, Sheppard D. Phosphoramidon potentiates the increase in lung resistance mediated by tachykinins in guinea-pigs. Am Rev Respir Dis 1988; 137: 337-340.

75. Dusser DJ, Djokic TD, Borson DB, Nadel JA. Cigarette smoke induces bronchoconstrictor hyperresponsiveness to substance $\mathrm{P}$ and inactivates airway neutral endopeptidase in the guinea-pig: possible role of free radicals. J Clin Invest 1989; 84: 900-906.

76. Dusser DJ, Jacoby DB, Djokic TD, Rubinstein I, Borson DB, Nadel JA. Virus induces airway hyperresponsiveness to tachykinins: role of neutral endopeptidase. J Appl Physiol 1989; 67: 1504-1511.

77. Daffonchio L, Hernandez A, Gallico L, Omini C. Airway hyperreactivity induced by active cigarette smoke exposure in guinea-pigs: possible role of sensory neuropeptides. Pulm Pharmacol 1990; 3: 161-166.

78. Elwood W, Lötvall JO, Barnes PJ, Chung KF. Airway hyperresponsiveness to acetylcholine and to tachykinins after respiratory virus infection in the guinea-pig. Ann Allergy 1993; 70: 231-236.

79. Boichot E, Lagente V, Le Gall G, et al. Bronchial responses to substance $\mathrm{P}$ after antigen challenge in the guineapig: in vivo and in vitro studies. Med Inf 1992; 1: 207-212.

80. Erjefält I, Persson CGA. Pharmacologic control of plasma exudation into tracheobronchial airways. Am Rev Respir Dis 1991; 143: 1008-1014.

81. Lei YH, Barnes PJ, Rogers DF. Inhibition of neurogenic plasma exudation in guinea-pig airways by CP-96,345, a new nonpeptide $\mathrm{NK}_{1}$ receptor antagonist. Br J Pharmacol 1992; 105: 261-262.

82. Bertrand C, Geppeti P, Graf PD, Foresi A, Nadel JA. Involvement of neurogenic inflammation in antigeninduced bronchoconstriction in guinea-pigs. Am J Physiol 1993; 265: L507-L511.

83. Bertrand C, Geppetti P, Baker J, Yamawaki I, Nadel JA. Role of neurogenic inflammation in antigen-induced vascular extravasation in guinea-pig trachea. J Immunol 1993; 150: 1479-1485.

84. Rogers DF, Belvisi MG, Aursudkij B, Evans TW, Barnes PJ. Effects and interactions of sensory neuropeptides on airway microvascular leakage in guinea-pigs. $\mathrm{Br} J$ Pharmacol 1988; 95: 1109-1116.

85. Lazzaret F, Chauveau M, Weber S, Lockhart A, Frossard N. Inhibition of substance P-induced microvascular leakage by inhaled methoxamine in rat airways. Br J Pharmacol 1994; 113: 649-655.

86. Lötvall JO, Lemenn RJ, Hui KP, Barnes PJ, Chung KF. Airflow obstruction after substance $\mathrm{P}$ aerosol: contribution of airway and pulmonary oedema. J Appl Physiol 1990; 69: 1473-1478.

87. Umeno E, Nadel JY, Huang HT, McDonald DM. Inhibition of neutral endopeptidase potentiates neurogenic inflammation in the rat trachea. J Appl Physiol 1989; 66: 2647-2652.

88. Qian Y, Emonds-Alt X, Advenier C. Effects of capsaicin, ( \pm )-CP-96,345 and SR 48968 on the bradykinininduced airways microvascular leakage. Pulm Pharmacol 1993; 6: 63-67.
89. Kraneveld AD, Buckley TL, van Heuven-Holsen Y, van Schaik Y, Koster AS, Nijkamp FP. Delayed-type hypersensitivity-induced increase in vascular permeability in the mouse small intestine: inhibition by depletion of sensory neuropeptides and $\mathrm{NK}_{1}$ receptor blockade. $\mathrm{Br} J$ Pharmacol 1995; 114: 1483-1489.

90. Walsh DT, Weg VB, Williams TJ, Noursharg S. Substance $\mathrm{P}$-induced inflammatory responses in guinea-pig skin: the effect of specific $\mathrm{NK}_{1}$ receptor antagonists and the role of endogenous mediators. $\mathrm{Br}$ J Pharmacol 1995; 114: 1343-1350.

91. Inoue $\mathrm{H}$, Nagata $\mathrm{N}$, Koshihara Y. Effect of the tachykinin receptor antagonists, SR 140333, FK 888 and SR 142801, on capsaicin-induced mouse ear oedema. Inflamm Res 1996; 45: 303-307.

92. Tousignant $\mathrm{C}$, Chan $\mathrm{CC}$, Guevremont $\mathrm{D}$, et al. $\mathrm{NK}_{2}$ receptors mediate plasma extravasation in guinea-pig lower airways. Br J Pharmacol 1993; 108: 383-386.

93. Biyah K, Molimard M, Emonds-Alt X, Advenier C. SR 140333, prevents potentiation by citric acid of plasma exudation induced by histamine in airways. Eur $J$ Pharmacol 1996; 308: 325-328.

94. Joos GF, Germonpre PR, Kips JC, Peleman RA, Pauwels RA. Sensory neuropeptides and the human lower airways: present state and future directions. Eur Respir J 1994; 7: 1161-1171.

95. Smith CH, Barker JNWN, Morris RW, McDonald DM, Lee TH. Neuropeptides induce rapid expression of endothelial cell adhesion molecules and elicit granulocyte infiltration in human skin. J Immunol 1993; 151: 3274-3282.

96. Iwamoto I, Tomoe S, Tomioka H, Yoshida S. Leukotriene B4 mediates substance P-induced granulocyte infiltration in mouse skin. J Immunol 1993; 151: 2116-2123.

97. Numao T, Agrawal DK. Neuropeptides modulate human eosinophil chemotaxis. J Immunol 1992; 149: 3309-3315.

98. Boichot E, Germain N, Emonds-Alt X, Lagente V, Advenier C. Effects of the tachykinin $\mathrm{NK}_{1}$ (SR 140333) and $\mathrm{NK}_{2}$ (SR 48968) receptor antagonists on antigen and substance P-induced activation of guinea-pig alveolar macrophages. Am J Respir Crit Care Med 1996; 153: A417.

99. Turner CR, Andresen CJ, Patterson DK, et al. Dual antagonism of $\mathrm{NK}_{1}$ and $\mathrm{NK}_{2}$ receptors by $\mathrm{CP} 99,994$ and SR 48968 prevents airway hyperresponsiveness in primates. Am J Respir Crit Care Med 1996; 153: A160.

100. Kaltreider HB, Ichikawa S, Byrd PK, et al. Upregulation of neuropeptide receptors in a murine model of immune inflammation in lung parenchyma. Am J Respir Cell Mol Biol 1997; 16: 133-144.

101. Kroegel C, Giembycz MA, Barnes PJ. Characterization of eosinophil cell activation by peptides: differential effects of substance P, mellitin and f-met-leu-phe. $J$ Immunol 1990; 145: 2581-2587.

102. Ruff MR, Wahl SM, Pert CB. Substance P receptormediated chemotaxis of human monocytes. Peptides 1985; 6: 107-111.

103. Marasco WA, Showell HJ, Becker EL. Substance P binds to the formylpeptide chemotaxis receptor on the rabbit neutrophil. Biochem Biophys Res Commun 1981; 99: 1065-1072.

104. Rabier M, Damon M, Chanez P, et al. Neutrophil chemotactic activity of PAF, histamine and neuromediators in bronchial asthma. J Lip Med 1991; 4: 265-275.

105. Perretti M, Ahluwalia A, Flower RJ, Manzini S. Endogenous tachykinins play a role in IL-1-induced neutrophil accumulation: involvement of NK-1 receptors. Immunology 1993; 80: 73-77. 
106. Payan DG, Goetzl EJ. Substance P receptor-dependent responses of leukocytes in pulmonary inflammation. $\mathrm{Am}$ Rev Respir Dis 1987;136: S39-S46.

107. Payan DG, Levine JD, Goetzl EJ. Modulation of immunity and hypersensitivity by sensory neuropeptides. $J$ Immunol 1984; 132: 1601-1604.

108. Laurenzi MA, Persson MA, Dalsgaard CJ, Ringden O. Stimulation of B-lymphocyte differentiation by the neuropeptides substance P and neurokinin A. Scand J Immunol 1989; 30: 695-701.

109. Harrison NK, Dawes KF, Kwon OJ, Barnes PJ, Laurent GJ, Chung KF. Effects of neuropeptides on human lung fibroblast proliferation and chemotaxis. Am J Physiol 1995; 268: L278-L283.

110. Lotz M, Vaughan JH, Carson DA. Effect of neuropeptides on production of inflammatory cytokines by human monocytes. Science 1988; 241: 1218-1221.

111. Serra MC, Calzetti F, Ceska M, Cassatella MA. Effect of substance $\mathrm{P}$ on superoxide anion and IL-8 production by human PMNL. Immunology 1994; 82: 63-69.

112. Calvo CF, Chavanel G, Senik A. Substance P enhances IL-2 expression in activated human T-cells. J Immunol 1992; 148: 3498-3504.

113. Baluk P, Bertrand C, Geppetti P, McDonald D, Nadel JA. $\mathrm{NK}_{1}$ receptors mediate leukocyte adhesion in neurogenic inflammation in the rat trachea. Am J Physiol (Lung Cell Mol Physiol 12) 1995; 268: L263-L269.

114. Lenique F, Jarreau PH, Boyer V, Harf A, MacquinMavier I. Tachykinins induce human neutrophil chemotaxis: involvement of $\mathrm{NK}_{2}$ receptors. Abstract. Fund Clin Pharmacol 1993; 7: 369.

115. Hartung HP, Toyka KV. Activation of macrophages by substance P: Induction of oxidative burst and thromboxane release. Eur J Pharmacol 1983; 89: 301-305.

116. Brunelleschi S, Vanni L, Ledda F, Giotti A, Maggi CA, Fantozzi R. Tachykinins activate guinea-pig alveolar macrophages: involvement of $\mathrm{NK}_{2}$ and $\mathrm{NK}_{1}$ receptors. Br J Pharmacol 1990; 100: 417-420.

117. Brunelleschi S, Parenti A, Ceni E, Giotti A, Fantozzi R. Enhanced responsiveness of ovalbumin-sensitized guinea-pig alveolar macrophages to tachykinins. $\mathrm{Br} \mathrm{J}$ Pharmacol 1992; 107: 964-969.

118. D'Ortho MP, Jarreau PH, Delacourt C, et al. Tachykinins induce gelatinase production by guinea-pig alveolar macrophages: involvement of $\mathrm{NK}_{2}$ receptors. Am J Physiol 1996; 269: L631-L636.

119. Pujol JL, Bousquet J, Grenier J, et al. Substance P activation of bronchoalveolar macrophages from asthmatic patients and normal subjects. Clin Exp Allergy 1989; 19: 625-628.

120. Tam EK, Aufderheide J, Hua XY. Chymotryptic activity in perfusates of isolated rat trachea: correlation with mucosal and connective tissue mast cell secretion. Am J Respir Cell Mol Biol 1994; 11: 321-328.

121. Lilly CM, Hall AE, Rodger IW, Kobzik L, Haley KJ, Drazen JM. Substance P-induced histamine release in tracheally-perfused guinea-pig lungs. $J$ Appl Physiol 1995; 78: 1234-1241.

122. Hua XY, Back SM, Tam EK. Substance P enhances electrical field stimulation-induced mast cell degranulation in rat trachea. Am J Physiol 1996; 270: L985-L991.

123. Mously M, Bueb JL, Bronner C, Rouot B, Landry Y. $\mathrm{G}$ protein activation: a receptor-independent mode of action for cationic amphiphilic neuropeptides and venom peptides. Trends Pharmacol Sci 1990; 11: 358-362.

124. Ellis JL, Undem BJ. Antigen-induced enhancement of noncholinergic contractile responses to vagus nerve and electrical field stimulation in guinea-pig isolated trachea. J Pharmacol Exp Ther 1992; 262: 646-653.

125. Colasurdo GN, Loader JE, Graves JP, Larsen GL. SPinduced contraction of airway smooth muscle in normal and allergen-sensitized rabbits: mechanism of action. $J$ Appl Physiol 1995; 78: 428-432.

126. Choudry NB, Fuller RW, Pride NB. Sensitivity of the human cough reflex: effect of inflammatory mediators, prostaglandin $\mathrm{E}_{2}$, bradykinin and histamine. Am Rev Respir Dis 1989; 140: 137-141.

127. Coleridge HM, Coleridge JCG, Ginzel KH, Baker DG, Banzett RB, Morrison MA. Stimulation of "irritant" receptors and afferent $\mathrm{C}$-fibres in the lung by prostaglandins. Nature (Lond) 1976; 264: 451-453.

128. Coleridge JCG, Coleridge HM. Afferent vagal C fibre innervation of the lungs and airways and its functional significance. Rev Physiol Biochem Pharmacol 1984; 99: $1-110$.

129. Bloomquist EI, Kream RM. Release of substance P from guinea-pig trachea leukotriene $\mathrm{D}_{4}$. Exp Lung Res 1990; 16: 645-659.

130. Ellis JL, Undem BJ. Role of peptidoleukotrienes in capasaicin-sensitive sensory fibre-mediated responses in guinea-pig airways. J Physiol (Lond) 1991; 436: 469-484.

131. Germonpre PR, Joos GF, Everaert E, Kips JC, Pauwels RA. Characterization of neurogenic inflammation in the airways of two highly inbred rat strains. Am J Respir Crit Care Med 1995; 152: 1796-1804.

132. Mitchell RW, Ndukwu IM, Herrnreiter A, et al. Differential tachykinin receptor subtype activation in capsaicin and $\mathrm{KCl}$ contractions of guinea-pig trachealis. Am J Physiol 1995; 269: L837-L842.

133. Riccio MM, Myers AC, Undem BJ. Immunomodulation of afferent neurons in guinea-pig isolated airway. $J$ Physiol 1996; 491: 499-509.

134. Riccio MM, Proud D, Undem BJ. Enhancement of afferent nerve excitability in the airways by allergic inflammation. Pulm Pharmacol 1995; 8: 181-186.

135. Kageyama N, Ichinose M, Igarashi A, et al. Repeated allergen exposure enhances excitatory nonadrenergic noncholinergic nerve-mediated bronchoconstriction in sensitized guinea-pigs. Eur Respir J 1996; 9: 1439-1444.

136. McDonald DM, Schoeb TR, Lindsey JR. Mycoplasma pulmonis infections cause long-lasting potentiation of neurogenic inflammation in the respiratory tract of the rat. J Clin Invest 1991; 87: 787-799.

137. McDonald DM. Upregulation of tachykinin receptors in chronic airway inflammation. Pulm Pharmacol 1995; 8: 203-206.

138. Baluk P, Bowden JJ, Lefevre PL, McDonald DM. Increased expression of substance $\mathrm{P}\left(\mathrm{NK}_{1}\right)$ receptors on airway blood vessels of rats with Mycoplasma pulmonis infection. Am J Respir Crit Care Med 1995; 151: A719.

139. Galeazza MT, Garry MG, Yost HJ, Strait KA, Hargreaves KM, Seybold VS. Plasticity in the synthesis and storage of substance $\mathrm{P}$ and calcitonin gene-related peptide in primary afferent neurons during peripheral inflammation. Neurosci 1995; 66: 443-458.

140. McCarson KE, Krause JE. $\mathrm{NK}_{1}$ and $\mathrm{NK}_{3}$ type tachykinin receptor mRNA expression in the rat spinal cord dorsal horn is increased during adjuvant or formayl-induced nociception. J Neurosci 1994; 14: 712-720.

141. Braunstein G, Fajac I, Lacronique J, Frossard N. Clinical and inflammatory responses to exogenous tachykinins in allergic rhinitis. Am Rev Respir Dis 1991; 144: 630-635. 
142. Ollerenshaw SL, Jarvis D, Sullivan CE, Woolcock AJ. Substance P-immunoreactive nerves in airways from asthmatics and nonasthmatics. Eur Respir J 1991; 4: 673-682.

143. Howarth PH, Djukanovic HR, Wilson JW, Holgate ST, Springall DR, Polak JM. Mucosal nerves in endobronchial biopsies in asthma and nonasthma. Int Arch Allergy Appl Immunol 1991; 94: 330-333.

144. Howarth PH, Springall DR, Redington AE, Djukanovic R, Holgate ST, Polak JM. Neuropeptide-containing nerves in endobronchial biopsies from asthmatic and nonasthmatic subjects. Am J Respir Cell Mol Biol 1995; 13: 288-296.

145. Lilly CM, Bai TR, Shore SA, Hall AE, Drazen JM. Neuropeptide content of lungs from asthmatic and nonasthmatic patients. Am J Respir Crit Care Med 1995; 151: 548-553.

146. Nieber K, Baumgarten CR, Rathsack R, Furkert J, Oehme P, Kunkel G. Substance P and endorphin-like immunoreactivity in lavage fluids of subjects with and without allergic asthma. J Allergy Clin Immunol 1992; 90: 646-652.

147. Tomaki M, Ichinose M, Miura M, et al. Elevated substance $\mathrm{P}$ content in induced sputum from patients with asthma and patients with chronic bronchitis. Am J Respir Crit Care Med 1995; 151: 613-617.

148. Adcock IM, Peters M, Gelder C, Shirasaki H, Brown $\mathrm{CR}$, Barnes PJ. Increased tachykinin receptor gene expression in asthmatic lung and its modulation by steroids. J Mol Endocrinol 1993; 11: 1-7.

149. Bai TR, Zhou D, Weir T, et al. Substance $\mathrm{P}\left(\mathrm{NK}_{1}\right)$ and neurokinin $\mathrm{A}\left(\mathrm{NK}_{2}\right)$ receptor gene expression in inflammatory diseases. Am J Physiol 1995; 269: L309-L317.

150. Spina D, Page CP. Airway sensory nerves in asthma: targets for therapy? Pulm Pharmacol 1996; 9: 1-18.

151. Lundberg JM, Saria A. Capsaicin-induced desensitization of airway mucosa to cigarette smoke, mechanical and chemical irritants. Nature 1983; 302: 251-253.

152. Satoh H, Lou YP, Lundberg JM. Inhibitory effects of capsazepine and SR 48968 on citric acid-induced bronchoconstriction in guinea-pigs. Eur J Pharmacol 1993; 236: 367-372.

153. Forsberg K, Karlsson J-A, Theodorssont E, Lundberg JM, Persson CGA. Cough and bronchoconstriction mediated by capsaicin-sensitive sensory neurons in the guineapig. Pulm Pharmacol 1988; 1: 33-39.

154. Lalloo UG, Fox AJ, Belvisi MG, Chung KF, Barnes PJ. Capsazepine inhibits cough induced by capsaicin and citric acid but not hypertonic saline in guinea-pigs. $J$ Appl Physiol 1995; 79: 1082-1087.

155. Laude EA, Higgins KS, Morice AH. A comparative study of the effects of citric acid, capsaicin and resiniferatoxin on the cough challenge in guinea-pig and man. Pulm Pharmacol 1993; 6: 171-175.

156. Armstrong DJ, Luck JC. A comparative study of irritant and type J receptors in the cat. Respir Physiol 1974; 21: 47-60.

157. Mohammed SP, Higenbottam TW, Adcock JJ. Effects of aerosol-applied capsaicin, histamine and prostoglandin $\mathrm{E}_{2}$ on airway sensory receptors of anaesthetized cats. $J$ Physiol 1993; 6: 51-66.

158. Jansco G. Pathobiological reactions of C-fibre primary sensory neurones to peripheral nerve injury. Exp Physiol 19925; 77: 405-431.

159. Takahama K, Fuchikama T, Isohama $\mathrm{Y}$, Kai H, Miyata $T$. Neurokinin A but not neurokinin B and substance $P$ induces codeine-resistant coughs in awake guinea-pigs. Regul Pept 1993; 42: 236-237.
160. Kohrogi H, Graf PD, Sekizawa K, Borson DB, Nadel JA. Neutral endopeptidase inhibitors potentiate substance $\mathrm{P}$ and capsaicin-induced cough in awake guinea-pigs. $J$ Clin Invest 1988; 82: 2063-2068.

161. Fox AJ, Bernareggi M, Lalloo UG, Chung KF, Barnes PJ, Belvisi MG. The effect of substance P on the cough reflex and airway sensory nerves in guinea-pigs. Am J Respir Crit Care Med 1996; 153: A161.

162. Joos GF, Pauwels RA, Van Der Straeten ME. Effect of inhaled substance $\mathrm{P}$ and neurokinin A on the airways of normal and asthmatic subjects. Thorax 1987; 42: 779-783.

163. Katsumata U, Sekizawa K, Inoue H, Sasaki H, Takishima $\mathrm{T}$. Inhibitory actions of procaterol, a beta ${ }_{2}$-stimulant, on substance P-induced cough in normal subjects during upper respiratory tract infection. $J$ Exp Med 1989; 158: 105-106.

164. Prabhakar NR, Runold M, Yamamoto Y, Lagercrantz H, Cherniack NS, von Euler C. Role of the vagal afferents in substance P-induced respiratory responses in anaesthetized rabbits. Acta Physiol Scand 1987; 131: 63-71.

165. Lalloo UG, Fox AJ, Bernareggi M, Belvisi MG, Chung $\mathrm{KF}$, Barnes PJ. Bradykinin sensitisation of airway sensory nerves: a mechanism for captopril-induced enhancement of the cough reflex. Am J Respir Crit Care Med 1996; 153: A162.

166. Lalloo UG, Koto H, Bernareggi M, Salmon M, Barnes PJ, Chung KF. Ozone-induced sensitisation of citric acidinduced cough reflex in awake guinea-pigs: role of bradykinin $\mathrm{B}_{2}$ and tachykinin $\mathrm{NK}_{2}$ receptors. Am J Respir Crit Care Med 1996; 153: A162.

167. Kaufman MP, Coleridge HM, Coleridge JCG, Baker DG. Bradykinin stimulates afferent vagal C-fibres in intrapulmonary airways of dogs. J Appl Physiol: Respirat Environ Exercise Physiol 1980; 48: 511-517.

168. Saria A, Lundberg JM, Skofitsch G, Lembeck F. Vascular protein leakage in various tissues induced by substance $\mathrm{P}$, capsaicin, bradykinin, serotonin, histamine and by antigen challenge. Naunyn Schmiedebergs Arch Pharmacol 1983; 324: 212-218.

169. Belvisi MG, Bernareggi M, Lalloo UG, Chung KF, Barnes PJ, Fox AJ. Inhibitory effect of nedocromil on sensitization of the cough reflex in guinea-pigs. Am J Respir Crit Care Med 1996; 153: A159.

170. Fuller RW, Choudry NH. Increased cough reflex associated with angiotensin converting enzyme inhibitor cough. Br Med J 1987; 295: 1025-1026.

171. O'Connel F, Thomas VE, Studham JM, O'Neill TP, Fuller RW, Pride NB. Cough sensitivity to inhaled capsaicin during naturally occurring upper respiratory tract infection. Am Rev Respir Dis 1993; 147: A714.

172. Advenier C, Girard V, Naline E, Vilain P and EmondsAlt X. Antitussive effect of SR 48968, a nonpeptide tachykinin NK2 receptor antagonist. Eur J Pharmacol 1993; 250: 169-171.

173. Girard V, Naline E, Vilain P, Emonds-Alt X, Adenier C. Effect of the two tachykinin antagonists, SR 48968 and SR 140333, on cough induced by citric acid in the unanaesthetized guinea-pig. Eur Respir J 1995; 8: 1110-1114.

174. Yasumitsu R, Hirayama Y, Imai T, Miyayasu K, Hiroi $\mathrm{J}$. Effects of specific tachykinin receptor antagonists on citric acid-induced cough and bronchoconstriction in unanaesthetized guinea-pigs. Eur J Pharmacol 1996; 300: 215-219.

175. Robineau P, Petit C, Staczek J, Peglion JL, Brion JD, Canet E. $\mathrm{NK}_{1}$ and $\mathrm{NK}_{2}$ receptors involvement in capsaicin-induced cough in guinea-pigs. Am J Respir Crit Care Med 1994; 149: A186. 
176. Forsberg K, Karlsson JA, Zackrisson C, Persson CGA. Selective inhibition of cough and bronchoconstriction in conscious guinea-pig. Respiration 1992; 59: 72-76.

177. Fuller RW, Collier JC. Sodium cromoglycate and atropine block the fall in FEV1 but not the cough induced by hypotonic mist. Thorax 1984; 39: 766-770.

178. Jackson DM. The effect of nedocromil sodium, sodium cromoglycate and codeine phosphate, on citric acidinduced cough in dogs. Br J Pharmacol 1988; 93: 609-612.

179. Evangelista S, Ballati J, Perretti F. MEN 10,627, a new selective $\mathrm{NK}_{2}$ receptor antagonist inhibits antigen-induced bronchoconstriction in sensitized guinea-pigs. Neuropeptides 1994; 26 (Suppl. 1): 39-40.

180. Fahy JV, Wong HH, Geppetti P, Nadel JA, Boushey HA. Effect of an $\mathrm{NK}_{1}$ receptor antagonist (CP 99,994) on hypertonic saline-induced bronchoconstriction and cough in asthmatic subjects. Am J Respir Crit Care Med 1994; 149: A1057.

181. Ujiie Y, Sekizawa K, Aikawa T, Sasaki H. Evidence for substance $\mathrm{P}$ as an endogenous substance causing cough in guinea-pigs. Am Rev Respir Dis 1993; 148: 1628-1632.

182. Fong TM, Anderson SA, Yuh H, Huang RRC, Strader C. Differential activation of intracellular effector by two isoforms of human neurokinin-1 receptor. Mol Pharmacol 1992; 41: 24-30.

183. Mantyh PW, Rogers SD, Ghilardi JR, Maggio JE, Mantyh CR, Vigna SR. Differential expression of two isoforms of the neurokinin-1 (substance $\mathrm{P}$ ) receptor in vivo. Brain Res 1996; 719: 8-13.

184. Tian Y, Wu L, Pu Y, Huang CC, Chung FZ. Structural motifs encoded by individual exons of the human neurokinin-1 receptor gene interact differentially with selective agonists and antagonists. J Neurochem 1996; 67: 1191-1199.

185. McLean S, Ganong P, Seymour PA, et al. Pharmacology of CP 99,994; a nonpeptide antagonist of the tachykinin neurokinin-1 receptor. J Pharmacol Exp Ther 1993; 267: 472-479.

186. Rupniak NMJ, Williams AR. Differential inhibition of foot-tapping and chromodacryorrhoea in gerbils by CNS penetrant and nonpenetrant tachykinin NK receptor antagonists. Eur J Pharmacol 1994; 265: 179-185.
187. Barnes PJ. Modulation of neurotransmission in airways. Physiol Rev 1992; 72: 699-729.

188. Frossard N, Barnes PJ. $\mu$-Opiod receptors modulate noncholinergic nerves in guinea-pig airways. Eur J Pharmacol 1987; 141: 519-521.

189. Persson CGA. Role of plasma exudation in asthmatic airways. Lancet 1986; ii: 1126-1128.

190. Boichot E, Lagente V, Carre C, Waltmann P, MenciHuerta JM, Braquet P. Bronchial hyperresponsiveness and cellular infiltration in the lung of guinea-pig sensitized and challenged by aerosol. Clin Exp Allergy 1991; 21: 67-76.

191. Boichot E, Richard MP, Paubert-Braquet M. Effect of cefadroxil on antigen-induced bronchial hyperresponsiveness and eosinophil accumulation in lung from sensitized guinea-pigs. Int Arch Allergy Immunol 1993; 102: 87-93.

192. Lagente V, Boichot E, Carre C, Guinot P, Mencia-Huerta JM, Braquet P. Effects of the platelet-activating factor antagonists, BN 52021 and BN 50730, on antigen-induced bronchial hyperresponsiveness and eosinophil infiltration in lung from sensitized guinea-pigs. Clin Exp Allergy 1993; 23: 1002-1010.

193. Spina D, McKenniff MG, Coyle AJ, et al. Effect of capsaicin on PAF-induced bronchial hyperresponsiveness and pulmonary cell accumulation in the rabbits. $\mathrm{Br} J$ Pharmacol 1991; 103: 1268-1274.

194. Advenier C, Naline E, Toty L, et al. Effects on the isolated human bronchus of SR 48968, a potent and selective nonpeptide antagonist of the neurokinin A $\left(\mathrm{NK}_{2}\right)$ receptors. Am Rev Respir Dis 1992; 146: 11711181 .

195. Joos GF, Scoor JV, Kips JC, Pauwels RA. The effect of inhaled FK224, a tachykinin NK-1 and NK-2 receptor antagonist, on neurokinin A-induced bronchoconstriction in asthmatics. Am J Respir Crit Care Med 1996; 153: $1781-1784$.

196. Van Schoor J, Joos GF, Chasson B, Brouard RJ, Pauwels RA. The effect of SR 48968, a nonpeptide neurokinin2 receptor antagonist on neurokinin A-induced bronchoconstriction in asthmatics. Eur Respir J 1996; 9: 289 s. 